\title{
The effect of nutritional management in early lactation and dairy cow genotype on milk production, metabolic status, and uterine recovery in a pasture-based system
}

\author{
E. L. Brady, ${ }^{1 *} \odot$ K. M. Pierce, ${ }^{2} \odot$ M. B. Lynch, ${ }^{2} \odot$ A. G. Fahey, ${ }^{2} \odot$ and F. J. Mulligan ${ }^{1} \oplus$ \\ ${ }^{1}$ School of Veterinary Medicine, University College Dublin, Belfield, Dublin 4, Ireland \\ ${ }^{2}$ School of Agriculture and Food Science, University College Dublin, Belfield, Dublin 4, Ireland
}

\begin{abstract}
High levels of milk production coupled with low feed intake cause negative energy balance in early lactation, especially in the first month postpartum (PP). Therefore, specific nutritional management at this time may improve nutritional and metabolic status with the possibility of contrasting genotypes responding differently. Thus, the objective of this study was to compare the effects of nutritional management strategies and dairy cow genotype on milk production, metabolic status, and some fertility parameters during early lactation in a pasture-based system. Sixty Holstein Friesian cows were blocked on parity and genotype [low-fertility highmilk (LFHM) and high-fertility low-milk (HFLM)] and were randomly assigned to 1 of 2 treatments in a 2 $\times 2$ factorial arrangement, in a randomized complete block design based on calving date, previous 305-d milk yield, and precalving body condition score (BCS). The nutritional management treatments were: (1) ad libitum access to fresh pasture plus an allowance of $3 \mathrm{~kg}$ of concentrates per day (CTR, $\mathrm{n}=30)$; and (2) ab libitum access to a tailored total mixed ration ( $\mathrm{TMR}, \mathrm{n}=30$ ). These diets were offered for the first $30 \mathrm{~d}$ PP. Following the first $30 \mathrm{~d} \mathrm{PP}$, cows fed TMR joined the CTR treatment and were managed similarly until $100 \mathrm{~d}$ PP. Blood samples were taken at d 7, 14, 21, and $28 \mathrm{PP}$ to determine metabolic status. Milk samples for composition analysis were collected weekly and BCS assessed every 2 wk. Genotype had a significant effect on milk output, whereas LFHM had increased fat $(+0.28 \mathrm{~kg} / \mathrm{d})$ and fat-plus-protein $(+0.17 \mathrm{~kg} / \mathrm{d})$ yield in the first 30 d PP compared with HFLM cows. The LFHM group also exhibited higher protein and lactose yields over the first $100 \mathrm{~d}$ PP. Nutritional management did create significant differences in milk composition in the first 30 d: TMR cows had lower protein, milk urea nitrogen,
\end{abstract}

Received July 21, 2020.

Accepted November 27, 2020

*Corresponding author: elaine.brady@ucdconnect.ie and casein concentration and higher lactose concentration than CTR cows. Over the first $100 \mathrm{~d}$ PP, TMR cows had higher fat-plus-protein and lactose yields. Feeding TMR reduced concentrations of nonesterified fatty acids $(-0.12 \mathrm{mmol} / \mathrm{L})$ and $\beta$-hydroxybutyric acid $(-0.10 \mathrm{mmol} / \mathrm{L})$ compared with the CTR group. Cows fed TMR had smaller BCS losses from calving to $60 \mathrm{~d}$ PP. There was no effect of any treatment on uterine recovery. Cows in the LFHM group demonstrated greater milk production in the first 30 and $100 \mathrm{~d}$ in milk. These results demonstrate that feeding cows a TMR for the first month of lactation has positive effects on milk output, metabolic status, and BCS profile.

Key words: dairy cow, grazing, early lactation, metabolic status, genotype

\section{INTRODUCTION}

During early lactation, dairy cows experience a rapid increase in milk yield coupled with a low DMI. Due to this imbalance, dairy cows enter an inevitable state of negative energy balance (NEB), resulting in adipose tissue mobilization and poor metabolic status. An increase in the circulating concentrations of nonesterified fatty acids (NEFA) and BHB in the weeks following calving is part of normal adaptation to NEB in early lactation (Drackley and Andersen, 2006). Thus, even though NEB cannot be prevented, many researchers believe the severity and duration of NEB should be reduced, because excess concentrations of NEFA $(>0.7$ $\mathrm{mmol} / \mathrm{L})$ and $\mathrm{BHB}(>1.2 \mathrm{mmol} / \mathrm{L})$ are detrimental to production and reproductive outcomes, animal health, and immune system function (Hammon et al., 2006; Ospina et al., 2010; Compton et al., 2015).

Early introduction to pasture and a compact calving period (Dillon et al., 2005) are necessary in seasonalcalving pasture systems to keep production costs low (Finneran et al., 2010). Nevertheless, a pasture-based diet is typically associated with a lower DMI compared with a TMR-based diet (Bargo et al., 2003). This lower DMI, together with very high levels of protein 
(Westwood et al., 2000) in typical ryegrass pasture and exposure to undesirable weather conditions may extend the period of NEB and poor metabolic status.

The use of TMR during the first month in early lactation may help overcome these challenges by increasing DMI and providing a higher allowance of glucogenic nutrients, effective fiber, and a balanced amount of RDP. This supply of balanced nutrients could aid in the quick resolution of a range of physiological, endocrine, and tissue remodeling processes required for good metabolic status and reproductive efficiency. Previous research has reported improved energy balance and reduced metabolite concentrations when specific nutrient management in early lactation is applied (van Knegsel et al., 2007a; Al Ibrahim et al., 2013). Offering a glucogenic diet has been shown to improve fertility phenotypes such as an earlier increase in progesterone (van Knegsel et al., 2007a), reduced postpartum anovulatory interval, and an increase in pregnancy rate (Burke and Roche, 2007). It is important to determine whether such improvements in metabolic status are possible in current dairy cow genotypes and whether similar improvements are possible in contrasting genotypes.

However, very limited research is available investigating the effect of TMR feeding for a short period in early lactation followed by grazing for the remainder of the lactation. To our knowledge, Al Ibrahim et al. (2013) is at present the only study investigating feeding TMR for the first $30 \mathrm{~d}$ postpartum (PP) in comparison to grazing. Nonetheless, no comparisons were made in that study to advocated feeding practices used in temperate grazing regions to maximize grass utilization of grazing cows nor was there any consideration of the effect of cow genotype on the response.

In Ireland, the economic breeding index (EBI) is used to identify suitable genetics for Irish pasturebased systems. The EBI is relatively new, having been established in 2001 (Veerkamp et al., 2002; Berry et al., 2007), but it is changing rapidly due to advances in technology and genomic selection. Recent research has validated the current EBI in terms of milk production (O'Sullivan et al., 2019b) and fertility performance (O'Sullivan et al., 2020) under varying levels of feeding management. However, none of this research evaluated TMR for the first $30 \mathrm{~d}$ as a strategy. Additionally, it is possible to have different subindex profiles for herds of similar overall EBI, depending on the breeding strategy followed on farms. For many grazing farms, fertility is a major focus, with modest emphasis on milk volume. However, farmers with limited land or resources may have followed a breeding strategy for high milk volume.

Therefore, the objective of this study is to compare the effects of contrasting nutritional management strategies - short-term TMR feeding versus cows allocated pasture - in early lactation and dairy cow genotype on milk production, metabolic status, and uterine recovery for grazing cows.

\section{MATERIALS AND METHODS}

\section{Animals and Management}

All procedures described in this experiment were approved by the Animal Research Ethics Committee of University College Dublin and were conducted under the experimental license from the Health Products Regulatory Authority under the European directive 2010/63/EU and S.I. No. 543 of 2012. Each person who carried out procedures during this experiment held an individual authorization from the Health Products Regulatory Authority.

Forty-four multiparous and 16 primiparous dairy cows (strain Holstein-Friesian) were selected from the spring-calving dairy herd at University College Dublin Lyons Research Farm, Celbridge, Naas, Co. Kildare, Ireland $\left(53^{\circ} 17^{\prime} 56^{\prime \prime} \mathrm{N}, 6^{\circ} 32^{\prime} 18^{\prime \prime} \mathrm{W}\right)$. Animals were blocked by parity and genotype and assigned to treatments based on expected calving date, previous 305-d milk yield and precalving BCS. The experiment was a randomized complete block design with a $2 \times$ 2 factorial arrangement of the treatments, nutritional management (NM), and genotype (G). In this study cows were selected from the multitrait EBI (Berry et al., 2007), based on 2 selection theories: fertility and milk PTA. Genetic evaluations were based on the 2019 EBI evaluation figures from the Irish Cattle Breeding Federation (ICBF), which manages the Irish national database (https://www.icbf.com/wp/), comprising the details of dairy and beef cattle born in Ireland. All animals were genotyped to increase the reliability of the predicted EBI. Within each treatment an equal number of cows with a low-fertility subindex $(26.5 \pm$ $20.4)$ and high-milk PTA $(118.1 \pm 125.7$; LFHM $)$ and high-fertility subindex $(93.8 \pm 20.7)$ and low-milk PTA $(-30 \pm 93.8 ;$ HFLM $)$ were randomly assigned to 1 of 2 NM strategy treatments at calving.

The 2 NM strategies were as follows: (1) from d 1 $\mathrm{PP}$, cows had fulltime access to pasture, predominantly perennial ryegrass, plus $3 \mathrm{~kg}$ of concentrates $(2.64 \mathrm{~kg}$ DM; Table 1: pasture concentrate) per cow per day (CTR, n = 30); or (2) from d 1 to d 30 PP, cows were housed and were offered TMR ad libitum with a starting allowance of $21 \mathrm{~kg}$ DM of TMR per day (TMR, $\mathrm{n}=30$ ). Subsequent feed allowances were made to ensure a $10 \%$ refusal ensuring ad libitum access. The TMR consisted of $27.6 \%$ maize silage, $20.7 \%$ grass silage, $28.6 \%$ concentrates (Table 1: TMR concentrates), $12.1 \%$ unmolassed beet pulp, $4.0 \%$ soybean meal and 
Table 1. Ingredient composition of pasture and TMR concentrate

\begin{tabular}{|c|c|c|}
\hline Ingredients (\% DM) & $\begin{array}{c}\text { Pasture } \\
\text { concentrate }^{1}\end{array}$ & $\begin{array}{c}\text { TMR } \\
\text { concentrate }^{2}\end{array}$ \\
\hline Barley & 21.7 & 21.7 \\
\hline Maize & 22.5 & 22.5 \\
\hline $\begin{array}{l}\text { Maize distiller dried grains } \\
\text { with solubles }\end{array}$ & 10.0 & 10.0 \\
\hline Sugarbeet pulp pellets $8 \mathrm{~mm}$ & 10.2 & 9.0 \\
\hline Soybean meal $47 \%$ & 13.5 & 21.0 \\
\hline Soy hulls & - & 5.0 \\
\hline Palm oil (Mixer) & 0.50 & 0.50 \\
\hline Palm oil (Coater) & 1.0 & 1.0 \\
\hline Sugarcane molasses (Mixer) & 4.5 & 4.5 \\
\hline Mono dicalcium phosphate & 4.59 & 0.8 \\
\hline Calcium carbonate & 2.07 & 0.8 \\
\hline AcidBuff $^{3}$ & 2.67 & 1.0 \\
\hline Sodium chloride $(\mathrm{NaCl})$ & 2.63 & 0.9 \\
\hline Magnesium oxide (MgO) & 2.0 & 0.75 \\
\hline Alltech Lifeforce MinPlex Pack ${ }^{4}$ & 0.0134 & 0.05 \\
\hline Vit E 5\% Premix & 0.0134 & 0.05 \\
\hline Biotin 2\% Premix & 0.033 & 0.0125 \\
\hline Yea-Sacc TS $(50 \% \text { Premix })^{4}$ & 0.067 & 0.025 \\
\hline Gain Cattle Premix ${ }^{5}$ & 1.07 & 0.40 \\
\hline
\end{tabular}

${ }^{1}$ Pasture concentrates: $2.64 \mathrm{~kg}$ of DM/d was offered to cows allocated pasture (Gain Feeds, Portlaoise, Laois, Ireland).

${ }^{2} \mathrm{TMR}$ concentrates: $6.16 \mathrm{~kg}$ of $\mathrm{DM} / \mathrm{d}$ was offered within the TMR, plus $0.88 \mathrm{~kg}$ of DM/d in the parlor for the first $30 \mathrm{~d}$ postpartum (Gain Feeds).

${ }^{3}$ Celtic Sea Minerals, Cork, Ireland.

${ }^{4}$ Alltech, Nicholasville, KY.

${ }^{5}$ Gain Cattle Premix (Gain Feeds): grass concentrate: $3.20 \mathrm{~g} / \mathrm{kg} \mathrm{Ca}$, $1.33 \mathrm{~g} / \mathrm{kg} \mathrm{P}, 1.07 \mathrm{~g} / \mathrm{kg} \mathrm{Na}, 0.83 \mathrm{~g} / \mathrm{kg} \mathrm{K}, 1.79 \mathrm{~g} / \mathrm{kg} \mathrm{Cl}, 1.60 \mathrm{~g} / \mathrm{kg} \mathrm{Mg}$, $0.130 \mathrm{~g} / \mathrm{kg} \mathrm{Cu}, 0.002 \mathrm{~g} / \mathrm{kg}$ Se, vitamin A 17,072 IU $/ \mathrm{kg}$, vitamin D $4,268 \mathrm{IU} / \mathrm{kg}$, vitamin E 88.34 IU $/ \mathrm{kg}$; TMR Concentrate: $1.19 \mathrm{~g} / \mathrm{kg} \mathrm{Ca}$, $0.5 \mathrm{~g} / \mathrm{kg} \mathrm{P}, 0.4 \mathrm{~g} / \mathrm{kg} \mathrm{Na}, 0.88 \mathrm{~g} / \mathrm{kg} \mathrm{K}, 0.75 \mathrm{~g} / \mathrm{kg} \mathrm{Cl}, 0.66 \mathrm{~g} / \mathrm{kg} \mathrm{Mg}, 0.06$ $\mathrm{g} / \mathrm{kg} \mathrm{Cu}, 0.0008 \mathrm{~g} / \mathrm{kg} \mathrm{Se}$, vitamin A 6,400 IU/kg, vitamin D 1,600 IU/ $\mathrm{kg}$, vitamin E $33 \mathrm{IU} / \mathrm{kg}$.

$3.7 \%$ wheat straw. From d 31 PP, the TMR cows joined the CTR cows and received the same treatment as the CTR cows for the remainder of the experiment.

For CTR, the daily concentrate allocation was split between 2 equal feeds, which were offered via in-parlor feeders (Feedrite automatic system, Dairymaster, Tralee, Ireland) during milking. These feeders were calibrated before the experiment commenced. Concentrates were offered to individual cows once they entered the individual bails of the rotary parlor. For ease of cow management, TMR cows also received $1 \mathrm{~kg}$ of concentrates daily in the rotary parlor, also split between 2 equal feeds.

All cows were grazed together and were offered fresh pasture allocations twice daily $(12-21 \mathrm{~kg} \mathrm{DM} /$ cow total). Allocations started at $12 \mathrm{~kg}$ of $\mathrm{DM} /$ cow per day for freshly calved cows and increased as cows increased in DIM to coincide with increased intakes until peak intake of $\sim 21 \mathrm{~kg}$ of DM/cow per day was reached. Allocations were grazed to 4.5 to $5 \mathrm{~cm}(100 \mathrm{~kg}$ of DM/ha) to ensure cows were not restricted. Pregrazing herbage mass of the area to be grazed was determined using the cut and weigh method using a quadrat $\left(0.25 \mathrm{~m}^{2}\right)$ and shears (O'Donovan et al., 2002; Whelan et al., 2012). At 4 random locations in the area of the paddock to be grazed, an area $\left(0.25 \mathrm{~m}^{2}\right)$ was cut using a handheld shears (Bosch Isio shears, Bosch GmbH, Gerlingen, Germany) to a height of $4.5 \mathrm{~cm}$. Each $0.25-\mathrm{cm}^{2}$ sample of pasture was weighed, and a sample of pasture was taken for DM determination and chemical analysis. Pre- and postgrazing heights were measured using a rising plate meter (Jenquip, Feilding, New Zealand). Average pregrazing herbage mass was $1,515 \pm 413 \mathrm{~kg}$ of DM/ha. The chemical composition of the pasture and concentrates offered during this experiment is presented in Table 2.

\section{Data and Sample Collection}

Pasture and TMR samples were collected on alternate days and pooled for the experimental period, whereas concentrate, grass silage, maize silage, wheat straw, soybean meal, and beet pulp samples were collected weekly and pooled for the experimental period. Pasture and concentrates were dried at $55^{\circ} \mathrm{C}$ in a forced dried oven to determine DM. Animals were milked twice daily, at 0720 and $1500 \mathrm{~h}$, in a 40-unit rotary parlor (Dairy Master, Causeway, Kerry, Ireland). Milk metering and sampling systems (Dairy Master) in the rotary parlor enabled milk yield recording and milk sampling.

Table 2. Chemical composition of pasture, TMR and concentrates

\begin{tabular}{lcccc}
\hline Item & Pasture & TMR & $\begin{array}{c}\text { Pasture } \\
\text { concentrate }\end{array}$ & $\begin{array}{c}\text { TMR } \\
\text { concentrate }\end{array}$ \\
\hline DM (\%) & 17.5 & 38.6 & 88.7 & 88.2 \\
Chemical composition (\% of DM) & 22.1 & 15.5 & 15.0 & 17.7 \\
CP & 45.1 & 38.7 & 22.7 & 18.4 \\
NDF & 19.8 & 22.3 & 15.3 & 9.8 \\
ADF & 8.3 & 6.5 & 14.4 & 9.9 \\
Ash & 3.1 & 4.8 & 2.6 & 2.8 \\
Ether extract & 14.3 & - & - & -126.3 \\
Water-soluble carbohydrates & - & 20.1 & & 24 \\
Starch & & & & \\
\hline
\end{tabular}


Milk samples were taken weekly during consecutive a.m. and p.m. milkings, pooled according to production, and stored at $4^{\circ} \mathrm{C}$ in a preservative (Broad Spectrum Microtabs II, D\&F Control Inc., Norwood, MA). These milk samples were sent weekly to a commercial milk laboratory (Progressive Genetics, Dublin, Ireland) for analyses of milk components including milk fat, protein, lactose, SCC, MUN, casein, and fatty acids. Animal BW was recorded twice daily as animals exited the parlor through the automatic drafting system containing the weighing scales. As the cow entered the drafting system, the ID tag was read, and a set of front gates retained the cow for her weight to be recorded. Body condition score was determined as a consensus score by 2 trained operatives and was recorded every 2 wk following the a.m. milking using a scale of 1 to 5 in 0.25 increments (Edmonson et al., 1989).

Dry matter intake was determined at 22 to $27( \pm 3)$ DIM for both treatments. Individual feed intakes of the TMR cows were recorded using computerized feeding troughs (RIC system; Insentec B.V., Marknesse, the Netherlands). Pasture DMI was determined using the n-alkane technique of Dove and Mayes (2006). The CTR cows were dosed with a paper bolus impregnated with $500 \mathrm{mg}$ of the n-alkane n-dotriacontane (C32) for a period of $12 \mathrm{~d}$ following a.m. and p.m. milking. From d 6 to 12, samples of the concentrates, pasture, and feces were collected. Pasture samples were collected morning and evening using a quadrat and handheld shears. These samples were immediately dried at $55^{\circ} \mathrm{C}$ for $48 \mathrm{~h}$. Fecal samples for the CTR cows were collected before each milking, from natural defecation whenever possible, and, if not, samples were collected per rectum. These fecal samples were placed in a forced-air oven at $55^{\circ} \mathrm{C}$ for $72 \mathrm{~h}$ or until dry.

Blood samples were collected via jugular venipuncture once per week for 4 consecutive weeks for the determination of NEFA, BHB, and glucose. Blood samples for glucose analysis were harvested into a graytop 5-mL Vacutainer containing potassium oxalate and sodium fluoride (ref. 3668201; Becton, Dickinson and Company, Franklin, NJ) and centrifuged at 2,100 $\times$ $g$ for 20 min at $4^{\circ} \mathrm{C}$ for separation of plasma. Plasma samples were stored at $-20^{\circ} \mathrm{C}$ before analysis. Blood samples for the remaining analytes, NEFA and BHB, were harvested into a red-top 10-mL Vacutainer containing a clot activator (ref. 367896) and allowed to clot for $16 \mathrm{~h}$ at $4^{\circ} \mathrm{C}$ before centrifuging at $2,100 \times g$ for 20 min at $4^{\circ} \mathrm{C}$ for the separation of serum. These serum samples were stored at $-20^{\circ} \mathrm{C}$ before analysis.

Milk progesterone samples were also collected using the electronic milk meters 3 times per week (Monday, Wednesday, Friday) during the a.m. milking and stored at $-20^{\circ} \mathrm{C}$ in a preservative used for milk sampling before analysis. Progesterone concentrations were measured using an ELISA (DIAsource PROG-RIACT, cat. no. Kip1458; Diasource Immunoassay S.A., Louvain-la-Neuve, Belgium). Cows with 2 consecutive readings of progesterone $>3 \mathrm{ng} / \mathrm{mL}$ were considered to have an active corpus luteum.

Transrectal sonography was carried out on d 21 and $35 \mathrm{PP}$ with an ultrasound instrument (Easi-Scan 1, BCF Technology, Rochester, MN) equipped with a 7.5$\mathrm{MHz}$ linear-array transrectal transducer. Cross-sectional images of the cervix and uterine horns were obtained by placing the transducer accordingly. The middle part of the cervix and uterine horns were imaged and measured. The diameter was calculated as the mean of the maximum height and width of endometrium. During the sonography, the uterus was scored from 0 to 4 based on the uterine characteristics (visual presence of luminal fluid and appearance of the endometrium) used by Šavc et al. (2016) each time.

Vaginal discharge was obtained using a Metricheck device (Simcro, Hamilton, New Zealand) before each transrectal sonography on d 21 and $35 \mathrm{PP}$ and scored from 0 to 3 using the mucus scoring system from Williams et al. (2005).

\section{Sample Analyses}

Dried pasture, TMR, concentrate, grass silage, maize silage, beet pulp, and soybean meal samples were ground in a hammer mill fitted with a 1-mm screen (Lab Mill; Christy Turner, Suffolk, UK). The DM content of the samples was determined by drying at $105^{\circ} \mathrm{C}$ for $16 \mathrm{~h}$. Following this, ash concentration was determined by combustion in a muffle furnace (Nabertherm $\mathrm{GmbH}$, Lilienthal, Germany) at $550^{\circ} \mathrm{C}$ for $5 \mathrm{~h}$. Neutral detergent fiber and ADF were determined using the Van Soest et al. (1991) method adapted for the use in the Ankom 220 Fiber Analyzer (Ankom Technology Corp., Fairport, NY). The $\mathrm{N}$ contents of grass, TMR, and concentrates were determined by combustion (FP 528 Analyzer, Leco Corp., St. Joseph, MI). Crude protein was then determined as $\mathrm{N}$ concentration $\times 6.25$. Starch was determined using the Megazyme Total Starch Assay Procedure (Product No. KTSTA; Megazyme International Ireland Ltd., Wicklow, Ireland). Ether extract was determined using the Soxtec instrument (Tecator, Höganäs, Sweden) and light petroleum ether. The concentration of water-soluble carbohydrates (WSC) was determined as described by DuBois et al. (1956).

Concentration of the milk components, milk fat, protein, lactose, SCC, MUN, casein and fatty acids were determined in a commercial milk laboratory (National Milk Laboratories Ltd., Wolverhampton, UK) using mid-infrared spectrometry (Milko-Scan FT6000, Foss 
Electric, Hillerød, Denmark; Soyeurt et al., 2006). Values for FCM were calculated as follows: FCM $4 \%=$ $(0.4 \times$ milk, $\mathrm{kg} / \mathrm{d})+(15 \times$ fat, $\mathrm{kg} / \mathrm{d})$ (Gaines and Davidson, 1923).

Pasture DMI was determined by extracting n-alkanes from pasture, concentrate, and feces samples according to the method of Dove and Mayes (2006). Following extraction, samples were analyzed for concentrations of n-alkanes by GC using a Scion 456-GC (Scion Instruments, Scotland, UK) fitted with a 30-m capillary column with an internal diameter of $0.53 \mathrm{~mm}$, coated with $1.5 \mu \mathrm{m}$ of dimethylpolysiloxane (Agilent Technologies Ireland Ltd., Cork, Ireland).

Using these data, pasture DMI/cow per day was estimated using the following modified equation (Mayes et al., 1986):

Intake $(\mathrm{kg}$ of $\mathrm{DM} /$ cow per day $)=\frac{[(F i / F j)(D j+I c C j)-I c C i]}{[H i-(F i / F j H j)]}$,

where $F i$ and $F j$ are the concentrations of naturally occurring odd-chain (feed derived) and even-chained (dosed C32) n-alkane in feces, respectively $(\mathrm{mg} / \mathrm{kg}) ; H i$ and $H j$ are the concentrations of natural odd-chain and even-chain n-alkanes in pasture, respectively $(\mathrm{mg} / \mathrm{kg})$; $D j$ is the daily dose rate of the even-chained n-alkanes $(\mathrm{mg} / \mathrm{kg}) ; I c$ is the daily concentrate intake $(\mathrm{kg} / \mathrm{d}) ;$ and $C i$ and $C j$ are the concentrations of natural odd-chain and even-chain n-alkanes in concentrate feed $(\mathrm{mg} / \mathrm{kg})$, respectively.

Energy balance was estimated during this time [22$27( \pm 3)$ DIM] using the estimated DMI data. Energy balance was estimated as the differences between $\mathrm{NE}$ intake (NEI) and the sum of $\mathrm{NE}_{\mathrm{M}}$ and $\mathrm{NE}_{\mathrm{L}}$ (Jarrige, 1989). The following equations were used to calculate $\mathrm{NE}_{\mathrm{M}}$ and $\mathrm{NE}_{\mathrm{L}}$ (Jarrige, 1989):

$$
\begin{gathered}
\text { Maintenance requirement }\left(\mathrm{NE}_{\mathrm{M}} ; \mathrm{UFL} / \mathrm{d}\right)= \\
1.4+[0.6 \times(\mathrm{BW}, \mathrm{kg} / 100)]
\end{gathered}
$$

where UFL = unité fourragère lait. A further $10 \%$ for loose-housed cows or $20 \%$ for grazing activity allowance was added (Jarrige, 1989).

$$
\begin{aligned}
& \text { Milk production requirement }\left(\mathrm{NE}_{\mathrm{L}} ; \mathrm{UFL} / \mathrm{d}\right)= \\
& 0.054(\text { fat } \%)+0.031(\operatorname{protein} \%) \\
& +0.028(\text { lactose } \%)-0.015
\end{aligned}
$$

Blood samples were analyzed for NEFA (kit no. FA115) and BHB (kit no. RB1007) using enzymatic tests. Glucose (kit no. GL3816) was analyzed using the hexokinase test. All kits were from Randox Laboratories
Ltd. (Crumlin, UK). All blood analyses were carried out using a clinical blood analyzer (RX imola; Randox Laboratories Ltd.).

\section{Statistical Analysis}

The residuals of the data were checked for adherence to the normal distribution and homogeneity of variance using histograms and formal statistical tests as part of the univariate procedure of SAS (version 9.4, 2012; SAS Institute Inc., Cary, NC). Nonnormal data were transformed using a Box-Cox transformation analysis as described by Fahey et al. (2007). This was done by raising the variables to the power of lambda. The data for BHB and NEFA required transformation and were raised to the power of 0.25 and -0.25 , respectively. Somatic cell count required transformation and was raised to the power of -0.25 . The transformed data were used to calculate $P$-values, whereas the corresponding untransformed least squares means and standard errors are reported for clarity. Data were analyzed using the repeated-measures function MIXED procedure SAS (version 9.4, 2012) when variables had more than one observation per subject, such as milk variables, BW, BCS, and blood metabolites. The model included the fixed effects of treatments [nutritional management (NM); TMR vs. CTR, genotype (G); LFHM vs. HFLM, time $(\mathrm{T})$, and parity] and their interactions. Week of experiment was the repeated unit, and cow was the random effect. The repeated-measures (co)variance structure was selected based on the smallest Bayesian information criterion (BIC) value. The (co)variance matrices used were compound symmetry, unstructured, autoregressive, heterogeneous first-order autoregressive, or Toeplitz. Variables with a single data point such as BCS loss and BW change were analyzed using GLIMMIX procedure of SAS (version 9.4, 2012), with fixed effects of treatment, parity, and their interactions. Statistically significant differences between least squares means were tested using the PDIFF command, incorporating the Tukey test for pairwise comparison of the treatment means. When the interactions were not significant, the term was removed from the model. There were no significant 3-way interactions for any of the measured variables and, therefore, they were excluded from the data set. Statistical significance was assumed at $P<0.05$, and a tendency toward significance was assumed at $P \geq 0.05$ but $<0.10$.

\section{RESULTS}

\section{Dry Matter Intake, Milk Production and Composition}

Table 3 and Figure 1 show the effect of nutritional management in early lactation and dairy cow genotype 
on DMI, milk production, and milk composition for the first 30 DIM. A significant difference in DMI $(P=0.01)$ was found between NM treatments but not between G. No NM $\times$ G interactions were observed during this period in DMI or milk output but were observed in milk composition. Interactions between $\mathrm{NM}$ and $\mathrm{G}$ were found when comparing protein, casein, and SCC concentrations in milk during the first $30 \mathrm{~d}$ PP. Despite NM not having an effect on milk output during the 30 d PP, G tended to have an effect on milk yield and fat yield $(P=0.08)$ and had a significant effect on FCM $(P$ $=0.004)$. In terms of milk composition, fat percentage, protein percentage, casein, and MUN were significantly influenced by NM. Milk derived from TMR cows had lower protein percentage (3.36 vs. $3.57 \%, P<0.001)$, lower casein (2.61 vs. $2.76 \mathrm{~g} / 100 \mathrm{~g}$ of milk, $P=0.005$ ) and lower MUN (0.017 vs. $0.035, P<0.001$ ) compared with grass-derived milk. Additionally, TMR-derived milk had significantly lower MUFA $(P<0.001)$, PUFA $(P=0.002)$, and UFA $(P<0.001)$ compared with grass-derived milk; SFA did not significantly differ. Cows with an LFHM genotype produced milk with a higher protein percentage $(+0.02 \%, P<0.001)$ and lower casein concentration $(-0.08 \%, P<0.001)$.

Despite NM not having an effect on milk output during the first 30 DIM, results in Table 4 reveal that NM had a significant effect over a longer period (100 DIM, $P<0.001)$. Cows fed TMR had a significantly higher FCM $(P<0.001)$, fat-plus-protein yield $(P=0.005)$, and lactose yield $(P<0.001)$ over the first $100 \mathrm{~d}$ PP. Milk protein percentage remained significantly lower for TMR-fed cows $(P<0.001)$ until 100 DIM, whereas $\mathrm{G}$ had an effect on both protein yield and percentage and lactose yield and percentage. One interaction was observed during the first $100 \mathrm{~d}$ PP as HFLM had a significantly higher lactose output when fed TMR compared with the CTR (1.40 vs. $1.29 \mathrm{~kg} / \mathrm{d}$, respectively).

\section{Animal BW and BCS}

Nutritional management strategies in early lactation did not affect average BCS over the 30- or 100-d period PP (Table 5). No significant differences were found between NM strategies in terms of BCS nadir. However, a tendency was observed for TMR cows to lose less BCS $(P=0.06)$ to reach the BCS nadir compared with CTR cows but no significant differences in time to reach the BCS nadir were evident, as shown in Figure 2a. There was no difference in BCS loss at 30 or 100 DIM. Nonetheless, BCS loss was less severe up to 60 DIM for TMR compared with CTR cows (0.23 vs. 0.41 , respectively, $P=0.006$ ). No significant differences were observed between genotypes. Differences in BW were significant between treatments over the 30- and 100-d periods postpartum (Figure 3 ). The average BW of both genotypes did not differ significantly over the 100-d period; however, LFHM cows lost the least BW during the first $60 \mathrm{DIM}(P=0.01)$. No NM $\times \mathrm{G}$ interactions were found at any stage during the $100-\mathrm{d}$ period postpartum for BCS and BW.

\section{Energy Status, Blood Metabolites, and Uterine Recovery}

Table 6 shows the effect of NM and G on energy status and blood metabolites. The TMR cows had a higher NEI $(P=0.001)$ and lesser NEB $(P<0.001)$ than the CTR. However, NE output was not affected by NM $(P=0.17)$. Genotype tended to have an effect on both NE output $(P=0.08)$ and energy balance $(P$ $=0.06)$ : LFHM had a higher NE output and a higher NEB compared with HFLM. No interaction was found between NM and G within the energy status parameters.

No significant effects were seen in terms of NM or G on plasma glucose concentration. Cows fed TMR had lower NEFA concentrations $(0.38$ vs. $0.50 \mathrm{mmol} / \mathrm{L}, P$ $<0.03)$ and a tendency for lower BHB concentrations (0.70 vs. $0.80 \mathrm{mmol} / \mathrm{L}, P=0.05)$ compared with those allocated pasture PP. No NM $\times$ G interaction was observed. Nonetheless, a significant $G \times$ time interaction was noted in NEFA concentrations. Additionally, significant NM $\times$ time interactions were present in blood glucose and BHB concentrations. These results are displayed in Figure 4. Neither NM nor G had an effect on the different uterine recovery parameters presented in Table 7.

\section{DISCUSSION}

This study was undertaken to compare the effects of NM in the first $30 \mathrm{~d} \mathrm{PP}$ and dairy cow genotype on milk production, metabolic status, and uterine recovery. The diets used in the specific NM period reflect typical diet composition used on dairy farms. Therefore, the diets were not balanced in terms of nitrogen, energy, or fiber due to the contrasting nature of TMR- and pasture-based diets. We intended for the diets to reflect commercial practice on farms where these NM strategies might be used.

\section{Nutritional Management in Early Lactation}

Dry Matter Intake and Milk Production. Previous studies comparing TMR and pasture-based systems have reported a significant increase in DMI and milk yield when cows were offered TMR (O'Neill et al., 2011; O'Callaghan et al., 2016; Gulati et al., 
Brady et al.: POSTPARTUM NUTRITIONAL MANAGEMENT AND GENOTYPE

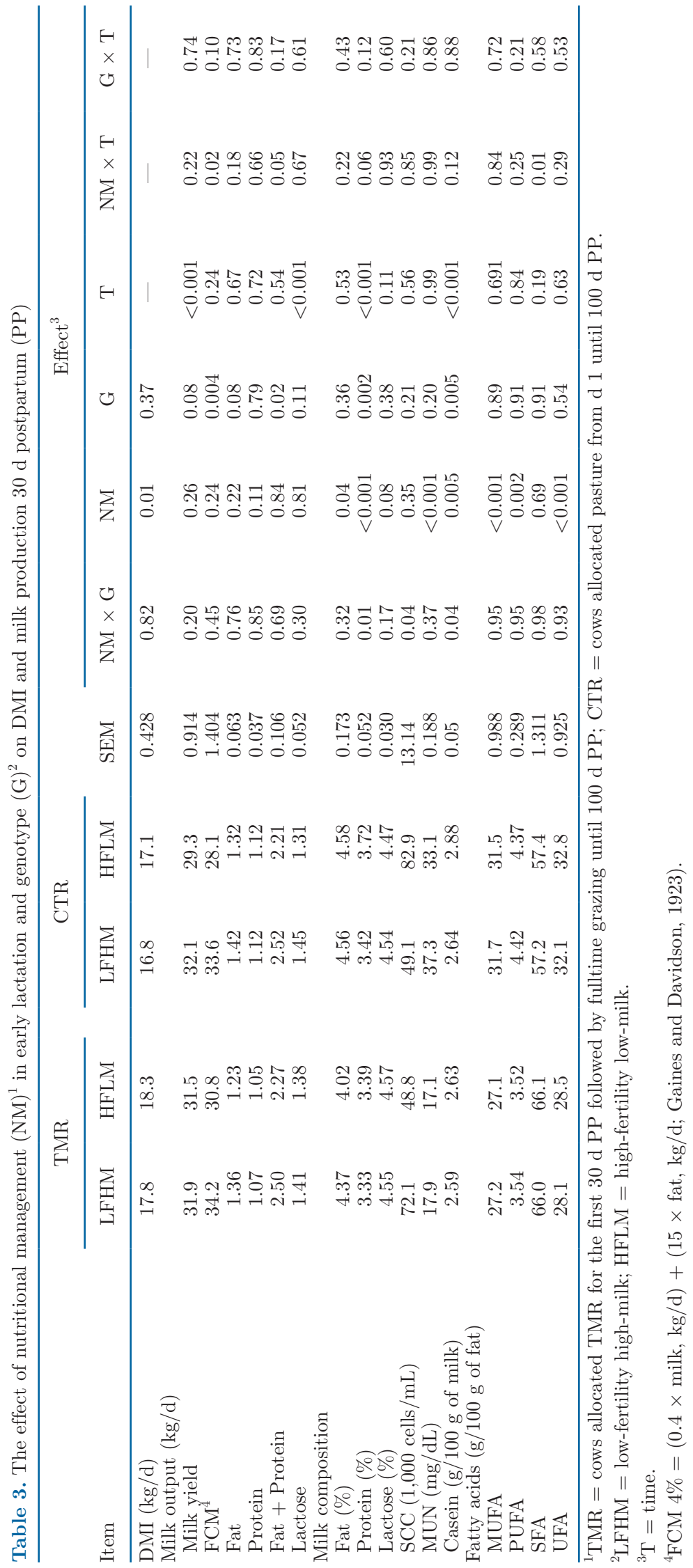




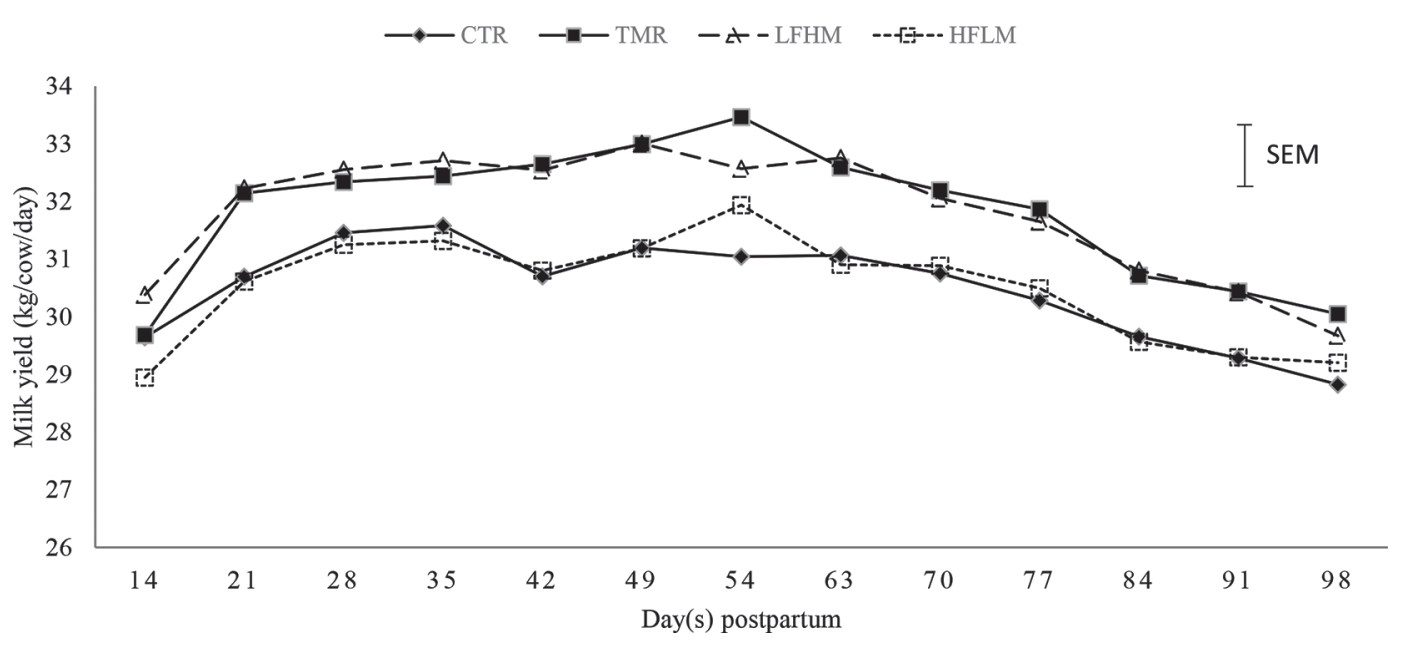

Figure 1. Effect of nutritional management and genotype in early lactation on milk yield $(\mathrm{kg} / \mathrm{d})$ over the duration of the study. CTR $=$ Cows allocated pasture from d 1 postpartum (PP) to d $100 \mathrm{PP}(\downarrow)$; TMR = cows allocated TMR for the first $30 \mathrm{~d}$ PP followed by fulltime grazing until 100 PP $(\mathbf{\square}) ;$ LFHM = low-fertility high-milk $(\Delta) ;$ HFLM = high-fertility low-milk $(\square)$.

2018). In contrast, in the present study, NM in the first $30 \mathrm{~d}$ did not improve milk output within the first $30 \mathrm{~d}$ despite the significant differences in DMI. The difference in DMI $( \pm 1.2 \mathrm{~kg}$ of $\mathrm{DM} / \mathrm{d})$ was smaller in this study than in other studies and its magnitude is a factor in the similar milk yields observed. Additionally, the lack of noteworthy differences in milk output within the first $30 \mathrm{~d}$ may be due to the higher starch and CP content of the TMRs used in the previous studies mentioned (O'Callaghan et al., 2016). The TMR formulation containing effective fiber and lower starch content would prevent SARA and related digestive disturbances (Penner et al., 2007), and lower CP would reduce the use of excess energy to remove urea from the system (Westwood et al., 2000). Stage of lactation may also play a role, as recent studies showed no differences in milk yield between feeding strategies until wk 8 of lactation (O'Sullivan et al., 2019b). Although no significant difference in milk output was observed within the specific NM period PP, the positive effects of short-term TMR feeding were observed in the data for the entire 100 DIM. Significant differences in milk yield were observed from wk 6 until wk 11 of lactation (Figure 1). Cows fed TMR in early lactation had a higher FCM $(+1.7 \mathrm{~kg})$, higher fat-plus-protein yield $(+0.12 \mathrm{~kg})$, and greater lactose yield $(+0.60 \mathrm{~kg})$ over the first $100 \mathrm{~d} \mathrm{PP}$. In a comparable study, examining a later introduction to grass PP, fat yield did have a tendency to be higher when fed TMR in early lactation followed by gradual introduction to pasture (Al Ibrahim et al., 2013). In the current study, despite the considerable difference in milk fat-plus-protein yield between TMR and CTR, no difference was found in milk fat percentage.
Grazing cows fed very different planes of nutrition on a short-term basis may not show as substantial difference in performance (Burke et al., 2010; Kennedy et al., 2015; Claffey et al., 2019). However, where grazing cows have been fed different planes of nutrition in early lactation for longer periods (2 vs. $6 \mathrm{wk}$ ), performance differences are evident (Kennedy et al., 2015; Claffey et al., 2019). Furthermore, some of these performance differences extend beyond the time of nutritional treatment. The gain in milk production $(+1.2 \mathrm{~kg}$ of milk/ day per cow) from cows fed TMR in the first $30 \mathrm{~d}$ PP in this trial was obvious between wk 6 and $11 \mathrm{PP}$.

In the present study, milk protein percentage $(3.38$ vs. $3.52 \%$ ) and casein (2.63 vs. $2.75 \mathrm{~g} / 100 \mathrm{~g}$ of milk) were significantly lower for TMR cows than for CTR cows in the first $100 \mathrm{~d}$. This is consistent with previous research comparing TMR to pasture-based systems in early lactation (O'Neill et al., 2011; O'Callaghan et al., 2016; Gulati et al., 2018). This may be due to the higher CP content of grass compared with TMR and is reflected in the higher MUN in all previously mentioned studies.

The UFA, such as C18:1 trans-11, in milk increase linearly as the proportion of grass in the cow's diet increases (Loor et al., 2003; Bargo et al., 2006; Couvreur et al., 2006). As a result, once both NM treatments were on the same pasture-based diet, no differences were found in terms of fatty acids measured (Table 4).

Energy and Metabolic Status, BCS, and BW. The influence of $\mathrm{NM}$ in the first $30 \mathrm{~d}$ is seen more clearly in terms of energy and metabolic status. As we hypothesized, the TMR cows had a significantly reduced NEB compared with the CTR cows ( -1.7 vs. 
Brady et al.: POSTPARTUM NUTRITIONAL MANAGEMENT AND GENOTYPE

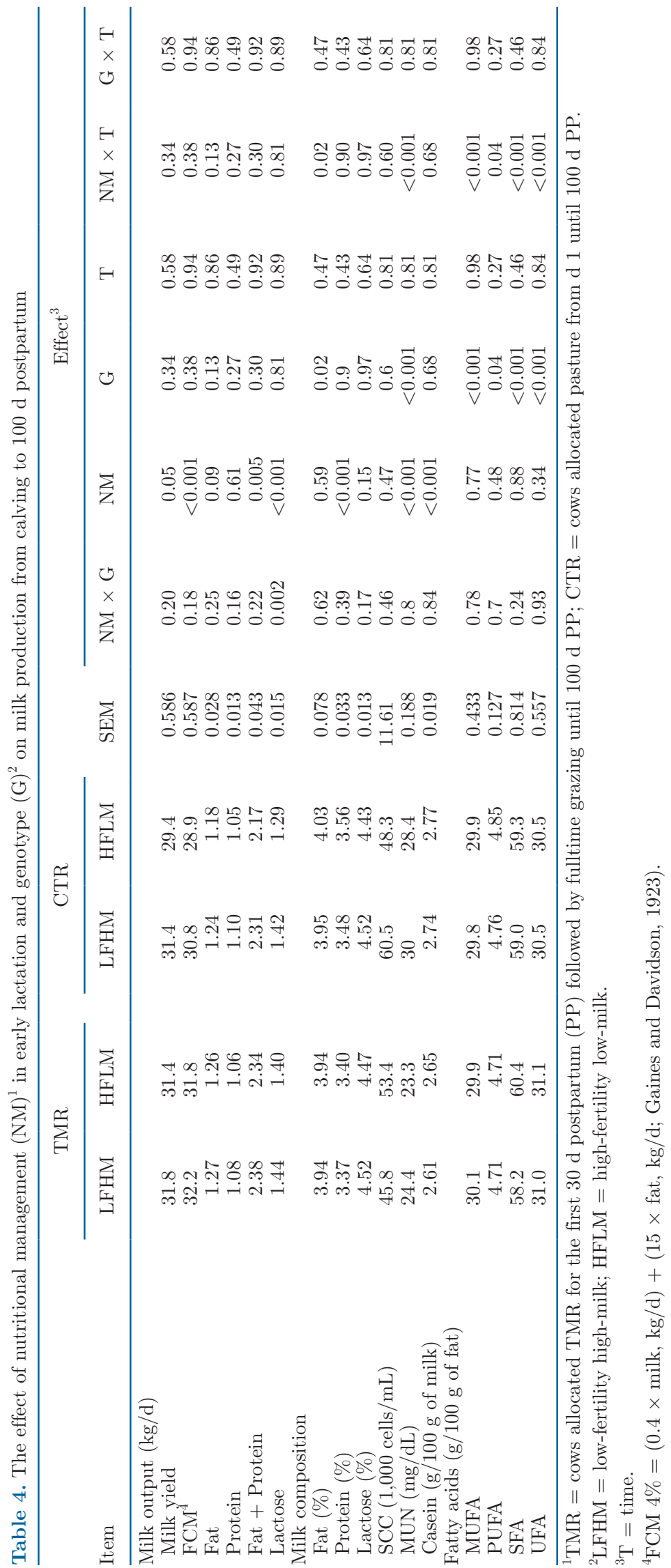


Table 5. The effect of nutritional management $(\mathrm{NM})^{1}$ in early lactation and genotype $(\mathrm{G})^{2}$ on BW and BCS over the 100-d postpartum period

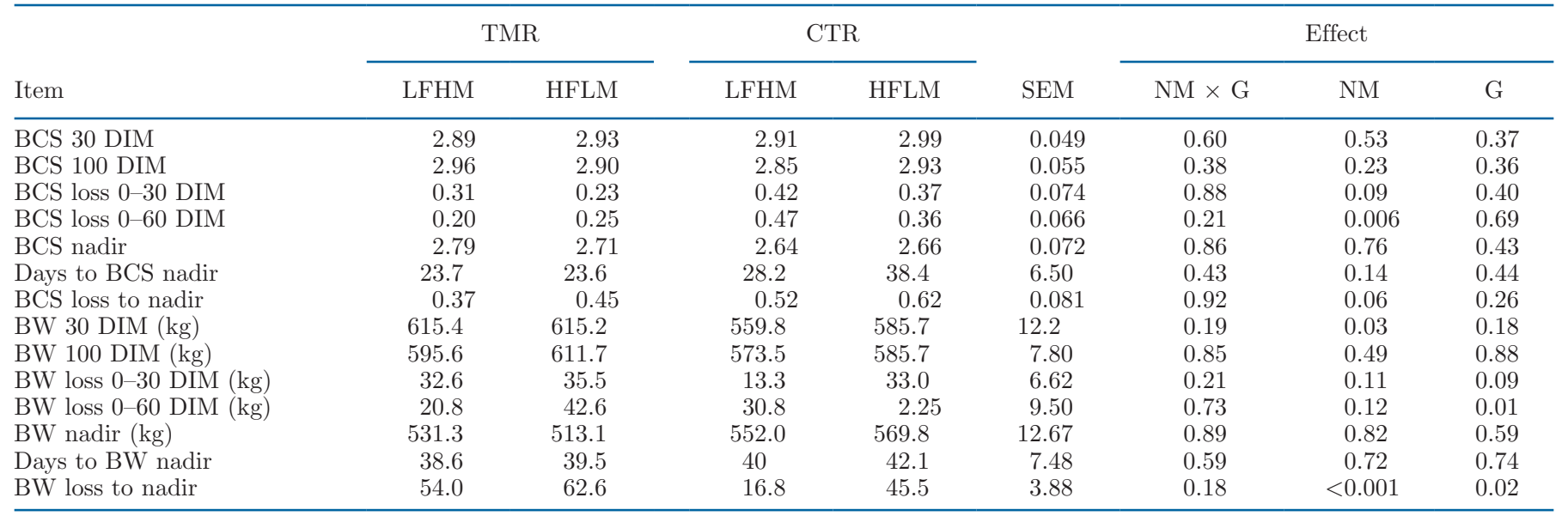

${ }^{1} \mathrm{TMR}=$ cows allocated TMR for the first $30 \mathrm{~d}$ postpartum $(\mathrm{PP})$ followed by fulltime grazing until $100 \mathrm{~d}$ PP; CTR $=$ cows allocated pasture from d 1 until $100 \mathrm{~d}$ PP.

${ }^{2}$ LFHM $=$ low-fertility high-milk; HFLM = high-fertility low-milk.

$-4.0 \mathrm{UFL} / \mathrm{d})$. This is largely due to the higher NEI of the TMR cows because the net energy output did not differ considerably between the NM treatments. This is apparent in the BCS data. In contrast to previous research (McCarthy et al., 2007; Roche et al., 2010; McDougall et al., 2018), NM tended to have an effect on BCS loss in the first $4 \mathrm{wk}$ of lactation (Table 5, Figure 2). In the current study, BCS nadir was reached 10 $\mathrm{d}$ earlier and cows tended to have a lower BCS loss to reach BCS nadir when on the TMR NM strategy. Astessiano et al. (2015) found similar trends when comparing TMR-fed cows to partial-TMR-fed cows. The study reflects the significant effects of grazing on BCS and metabolic status in early lactation despite cows only having 6- to 9-h grazing sessions. As grazing sessions increased from 6 to $9 \mathrm{~h}$, so did BCS loss and resulted in a lower BCS at +55 DIM. Nevertheless, in a similar study (Al Ibrahim et al., 2013), comparing contrasting introduction strategies to grazing in early lactation, did not have a significant effect on overall BCS, as it did in this study over the 30 - or $100-\mathrm{d}$ PP period. In the present study, for TMR cows, a shorter period of BCS loss was observed, resulting in a significantly lower BCS loss over the first $60 \mathrm{~d}$ PP compared with CTR cows (0.23 vs. 0.41 , respectively). These results indicate a persistent benefit of TMR feeding for a short period before being introduced to fulltime pasture grazing. As BCS is a physical reflection of energy balance, the lower BCS loss would suggest a quicker recovery and return to positive energy balance and BCS gain. Bodyweight at 30 DIM was significantly different between NM treatments $(+42.1 \mathrm{~kg}$ of BW; TMR) and tended to be so at d $100 \mathrm{PP}(+9.5 \mathrm{~kg}$ of BW; TMR). Much of the difference in $\mathrm{BW}$ at $30 \mathrm{~d}$ can be attributed to the
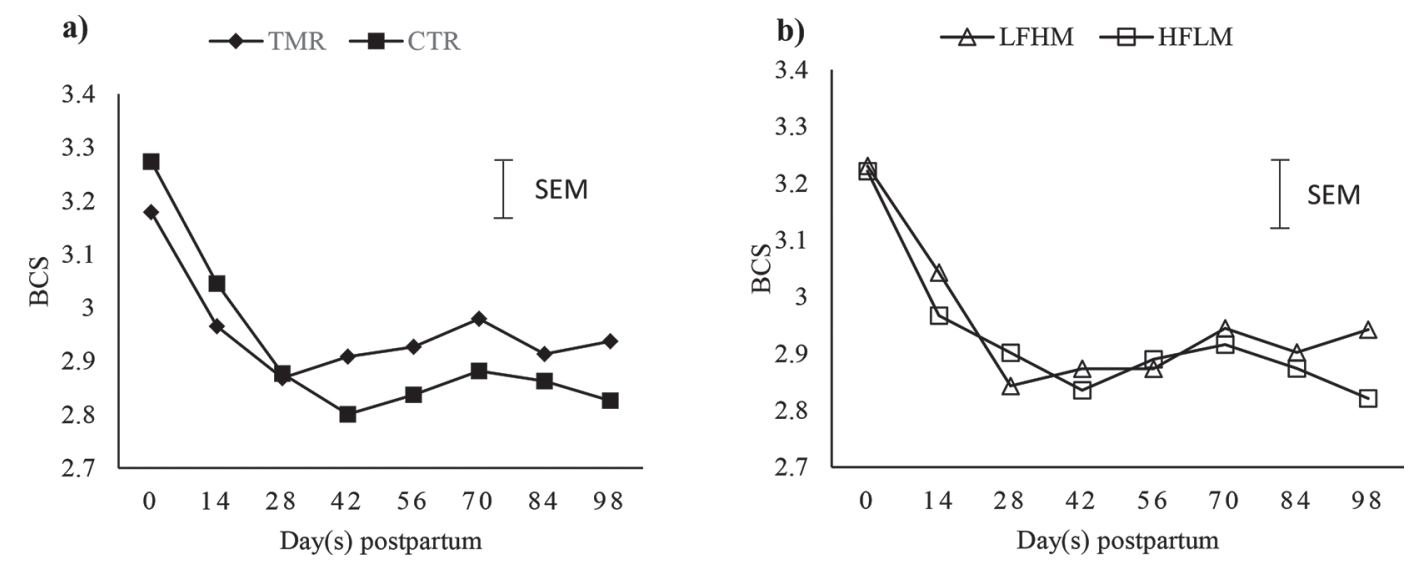

Figure 2. Effect of (a) nutritional management and (b) genotype in early lactation on BCS (Edmonson et al.,1989) over the duration of the study. TMR = cows allocated TMR for the first $30 \mathrm{~d}$ postpartum (PP) followed by fulltime grazing until $100 \mathrm{PP}(\bullet)$; CTR $=$ cows allocated pasture from d 1 PP to d $100(\square)$; LFHM = low-fertility high-milk $(\Delta)$; HFLM = high-fertility low-milk $(\square)$. 

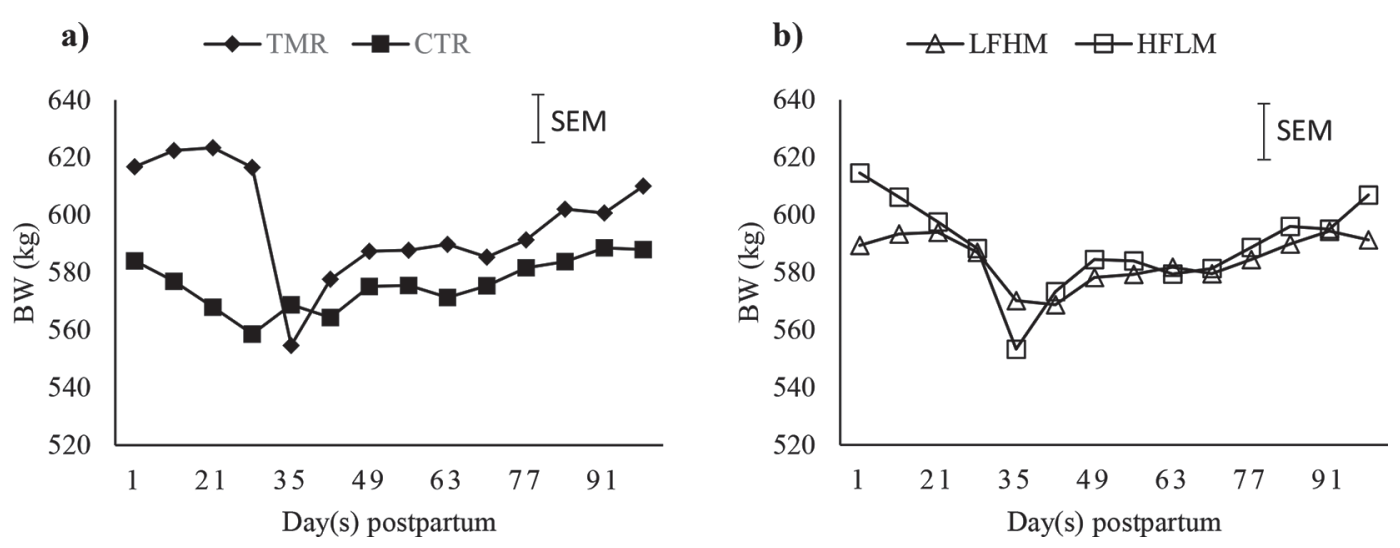

Figure 3. Effect of (a) nutritional management and (b) genotype in early lactation on BW over the duration of the study. TMR $=$ cows allocated TMR for the first $30 \mathrm{~d}$ postpartum (PP) followed by fulltime grazing until $100 \mathrm{PP}(\diamond)$; CTR = cows allocated pasture from d 1 PP to d $100(\mathbf{\square}) ;$ LFHM = low-fertility high-milk $(\Delta) ;$ HFLM = high-fertility low-milk $(\square)$.

higher gut fill in TMR (Chilliard et al., 1991) in the first $30 \mathrm{~d}$. This would also contribute to the greater BW loss between NM treatments over the 100 DIM due to the removal of TMR feeding at d 30 .

Nutritional management strategies that match the requirements of cows in early lactation more closely, may improve the energy status and therefore the health status of the cow (van Knegsel et al., 2007a,b). The positive effect of TMR feeding in early lactation on the energy status and BCS is reflected in the blood metabolites measured. The concentration of both NEFA and BHB in the blood were significantly lower for TMR cows than the CTR $(-0.12 \mathrm{mmol} / \mathrm{L}$ and $-0.10 \mathrm{mmol} / \mathrm{L}$, respectively). Grazing cows have a limited DMI and therefore limited energy intake. In comparison, offering a balanced TMR allows for higher DMI and therefore a higher total energy intake (Kolver and Muller, 1998). Due to the higher energy intake, mobilization of body reserves was reduced, and improved metabolic status was detected as observed in previous research with different feeding levels (Berry et al., 2006).

In addition to higher energy intake of TMR, cows in this group would have received a more consistent diet in the first 4 wk. The CTR cows would have been much more subjected to the influence of weather and grazing conditions on nutrient intake. The CTR cows would have had to adapt to changes in protein and energy availability on a weekly or daily basis (Smit et al., 2004). The excess $\mathrm{N}$ from grass is converted into urea by the liver and excreted mainly via milk, evident in the higher MUN values (Table 3), and in urine. Urea synthesis incurs a metabolic energy cost that imposes an additional stress factor on the already limited energy supply (Westwood et al., 2000; Kolver, 2003). All of these factors may have contributed to the higher NEFA and BHB concentrations of the CTR group.
Uterine Recovery. Emphasis has been placed on the negative effects of prolonged NEB in early lactation on the length of the anovulatory period PP and the reduced conception rates (Butler, 2003). A common strategy to overcome this is to increase dietary energy concentration such as increased starch or fat content to enhance the circulating of insulin concentration (Gong et al., 2002; Garnsworthy et al., 2008). The positive results from the BCS and blood metabolite data presented here did not translate into positive differences in the parameters measured for uterine recovery. In a previous study (Al Ibrahim et al., 2013), with lower cow numbers per treatment $(n=20)$, feeding TMR improved glucose and insulin concentrations, which had a tendency to have a positive influence on days to first ovulation, reducing the interval by $4 \mathrm{~d}(P$ $=0.09)$.

However, Gautam et al. (2010) found that cows with days to first ovulation beyond $35 \mathrm{~d}$ PP were associated with a reduced pregnancy rate. In this study, with no difference in postpartum anovulatory interval (PPAI) between treatments, cows ovulated before and within this timeframe increasing the probability of pregnancy. Within each treatment 7\% (2/29) of cows ovulated outside the 30-d window with no indicators of poor health identified. These results are consistent with previous pasture-based studies. These studies concluded that grazing multiparous cows appear to be unresponsive to feeding strategies in early lactation in altering the PPAI (Burke and Roche, 2007; Curran, 2016). Curran (2016) identified that Irish pasture-based dairy cows can exhibit adaptive response that place a high priority on fertility performance resulting in similar fertility outcomes in some parameters. This highlights the importance of harmonizing genotypes with their environment. 
The previous gravid horn can be identified up to 4 wk PP, but changes in diameter are almost imperceptible and are complete by wk 6 (Sheldon and Owens,
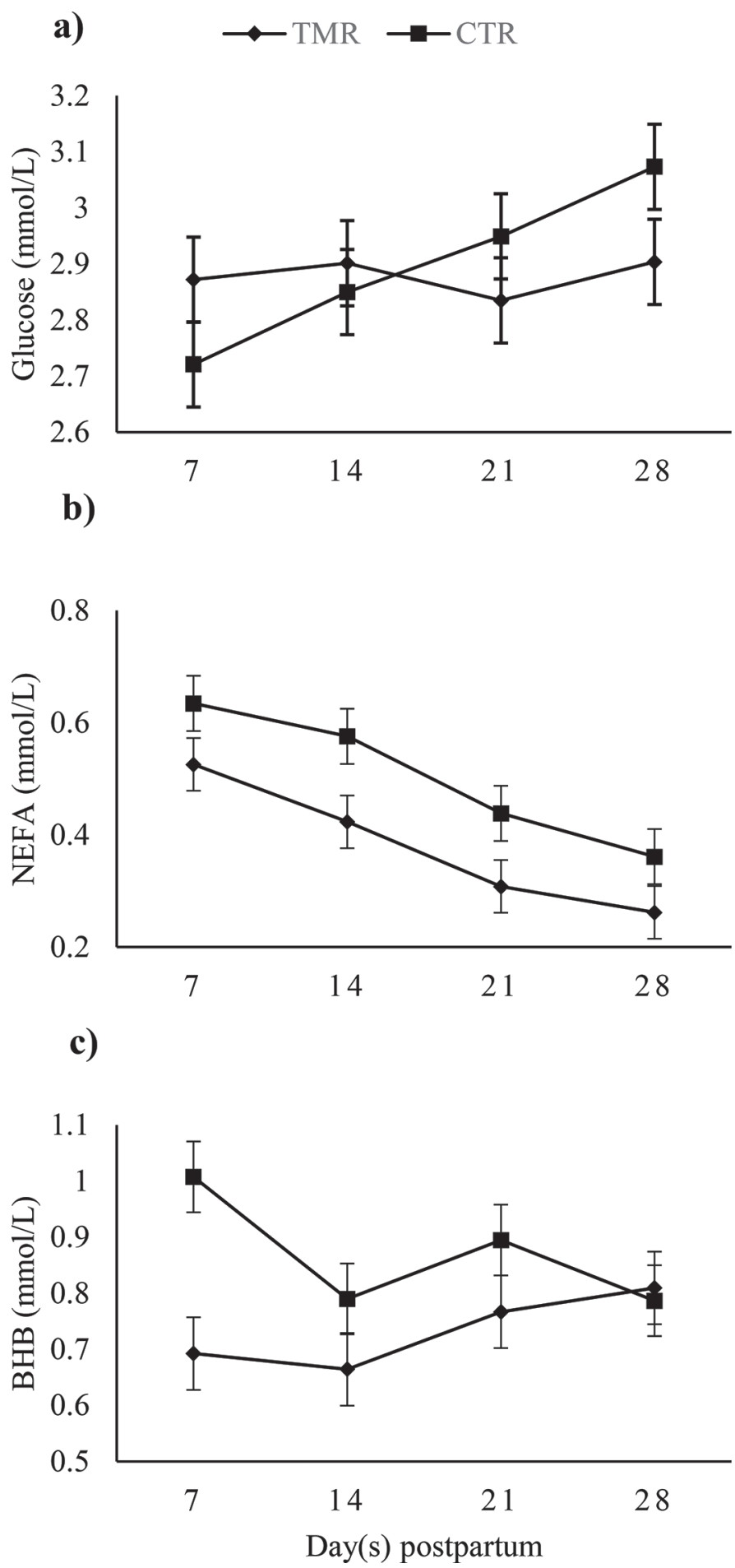

Figure 4. Mean circulating (a) glucose, (b) nonesterified fatty acids (NEFA), and (c) BHB concentrations in cows fed under different nutritional management strategies. TMR $=$ cows allocated TMR for the first $30 \mathrm{~d}$ postpartum (PP) followed by fulltime grazing until $100 \mathrm{~d}$ $\mathrm{PP}(\diamond) ; \mathrm{CTR}=$ cows allocated pasture from d $1 \mathrm{PP}$ to $100 \mathrm{~d} \mathrm{PP}(\mathbf{\square})$.

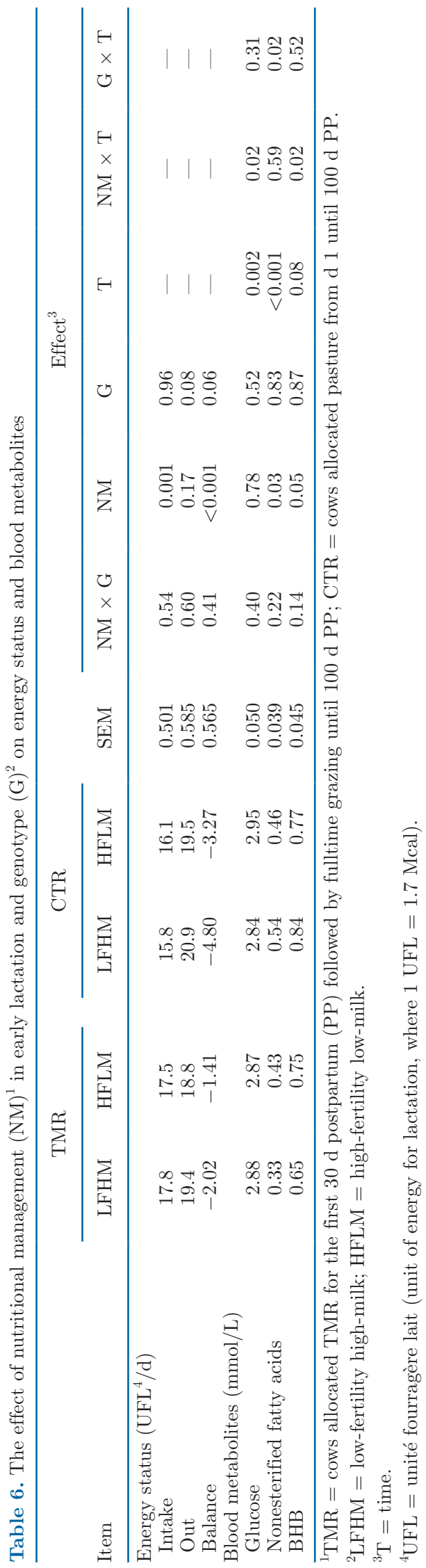


Table 7. The effect of nutritional management $(\mathrm{NM})^{1}$ in early lactation and dairy cow genotype $(\mathrm{G})^{2}$ on DTFO, peak progesterone $(\mathrm{P} 4)$ concentration, mucus and uterine score, and size of the gravid horn

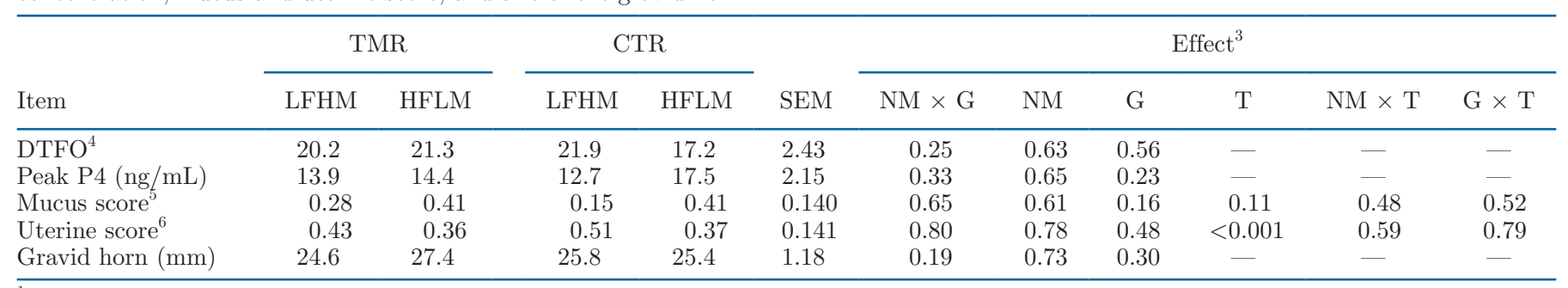

${ }^{1} \mathrm{TMR}=$ cows allocated TMR for the first $30 \mathrm{~d}$ postpartum $(\mathrm{PP})$ followed by fulltime grazing until $100 \mathrm{~d} \mathrm{PP} ; \mathrm{CTR}=$ cows allocated pasture from d 1 until $100 \mathrm{~d}$ PP.

${ }^{2} \mathrm{LFHM}=$ low-fertility high-milk cows; HFLM = high-fertility low-milk cows.

${ }^{3} \mathrm{~T}=$ time.

${ }^{4} \mathrm{DTFO}=$ days to first ovulation.

${ }^{5}$ Mucus score: $0=$ no or clear vaginal mucus, $1=$ mucus with specks of purulent material, $2=$ less than $50 \%$ pus, $3=$ more than $50 \%$ pus in the Metricheck sample (Williams et al., 2005).

${ }^{6}$ Uterine score: Uterine scores (0-4) of 2 and higher were defined as uteri with abnormal content and involution (Šavc et al., 2016).

2017). Ultrasound measurements were taken at $21 \mathrm{~d}$ $\mathrm{PP}$, at which time involution had already occurred in both CTR and TMR treatments. Heppelmann et al. (2013), observed limited change in uterine horn diameter after $25 \mathrm{~d}$ and most involution of the gravid horn was complete by d 18 . This may explain the small difference between treatments in the current study. No significant differences were found in mucous or uterine scores between treatments.

In summary, feeding TMR for the first $30 \mathrm{~d}$ PP improved metabolic status, positively altered BCS profile, and improved milk production parameters, but the limited uterine parameters assessed here were not improved.

\section{Genetic Effect}

It is apparent that heavy selection for milk production in the past has had a negative association with fertility (Berry et al., 2014). Modern selection indices have incorporated functional traits such as fertility, health, and fitness, reversing the decline in reproductive and other traits (Miglior et al., 2017). Genetic change is progressing rapidly with a combination of advances in technology and genomic selection. Hence, it is important to identify the correct or best suited genetics for each dairy system. Therefore, this study focused on the performance of genotypes contrasting in milk PTA and fertility subindex as these are major selection pathways for farmers. Interestingly, our hypothesis that the LFHM cows would have reduced uterine health compared with HFLM cows due to the higher milk potential was rejected.

Dry Matter Intake and Milk Production. The fertility subindex was the primary trait focused on in this study, whereby available cows were chosen based on their fertility subindex, ensuring a difference between the groups did not overlap. The corresponding PTA for milk yield of those cows also created a large overall difference between milk yield of LFHM and HFLM genotypes $(118.1 \pm 125.7$ vs. $-30 \pm 93.8$, respectively) within the EBI profile. Therefore, this was included in the genotype description. As we hypothesized, LFHM cows had higher milk output including higher milk yield $(+1.6 \mathrm{~kg})$, FCM yield $(+4.4 \mathrm{~kg})$, and fat-plus-protein $(+0.27 \mathrm{~kg})$ yields during the first $30 \mathrm{~d}$ PP. However, neither DMI nor NEI differed between the genotypes. This is consistent with a recent study comparing dairy cows of divergent EBI (O'Sullivan et al., 2019a). The findings of this study and those of O'Sullivan et al. (2019a) indicate that DMI per se is not affected by genotype, despite the differences in the EBI profile. Previous studies have found that cows with high milk merit have greater DMI on both pasture (Horan et al., 2006) and TMR (Kolver et al., 2002 ) diets. However, BW also plays an important role in DMI. The genotypes in this study did not differ in BW. Genetic selection for body size along with milk yield will on average increase genetic merit for DMI (Veerkamp and Brotherstone, 1997). The effect of G on milk output remained consistent over the 100 -d period. Higher milk production from cows of high milk genetic merit is consistent with previous research (Kennedy et al., 2003; Fulkerson et al., 2008). However, all grazing diets are somewhat restrictive and thus, high-milk-potential cows may have underperformed (Ferris, 2007) as a larger contrast between $\mathrm{G}$ milk yields was expected.

Irish genetic merit has changed over the last decade due to rapid genetic gain. This is evident in the results from this study as cows are more adaptable showing improved metabolic status and BCS despite higher milk output. The metabolic status and BCS of LFHM 
cows are similar to those of the HFLM cows regardless of the higher milk yield. Previously, cows of high genetic merit for milk production were associated with reduced BCS (McCarthy et al., 2007), and inferior metabolic status (Ingvartsen et al., 2003). More recent studies evaluating the effect of genotypes using the EBI profile, have focused on fertility traits, balancing the genetic potential for milk output between treatments (Cummins et al., 2012; Moore et al., 2014), limiting the effects of milk production on fertility. The most recent research evaluating the EBI, compared cows of divergent overall EBI. These studies highlighted the potential influence of genetics to deliver genetic and phenotypic gain by placing appropriate emphasis on traits of economic importance (O'Sullivan et al., 2019b; 2020). In the current study this is also evident with higher output in both milk yield and fat-plus-protein while maintaining a good metabolic status and reproductive outcomes.

Metabolic Status, BCS, and BW. Due to similar NEI between G, differences in milk output resulted in a tendency for increased NE output and consequently a tendency for greater NEB in the LFHM group ( -3.4 vs. $-2.3 \mathrm{UFL} / \mathrm{d}$ ) compared with the HFLM group. This is frequently observed in cows of higher milk potential (Horan et al., 2006; McParland et al., 2015). The extent of body reserve mobilization is usually associated with milk yield or with cows of higher genetic merit for milk production (Gong et al., 2002). Despite significant differences in energy status and milk output, mean BCS, and BCS change over the experimental period were similar for both genotype groups. This is reiterated in the overall blood metabolite results as no differences were observed between the 2 genotypes. However, a significant genotype by time interaction was observed whereby the LFHM cows at $\mathrm{d} 7 \mathrm{had}$ a higher level of NEFA concentrates ( 0.61 vs. $0.55 \mathrm{mmol} / \mathrm{L})$ but had a lower NEFA concentration at d 28 (0.28 vs. 0.34 $\mathrm{mmol} / \mathrm{L}$ ) than the HFLM cows. Body condition score and BCS change is predominantly under genetic control not only between breeds but between strains within breeds (Horan et al., 2005; Lucy et al., 2009; Cummins et al., 2012). Those strains within breeds that maintain a higher BCS tend to have a higher genetic merit for fertility (Cummins et al., 2012; Moore et al., 2014), which has been shown to be positively associated DMI and energy balance (Patton et al., 2007; Moore et al., 2014). However, looking more closely at the EBI profile of the LFHM, the subindex for maintenance is higher than for HFLM cows (5.96 vs. 2.65). This would suggest that using the EBI a higher production cow is able to maintain body reserves if maintenance subindex is adequate. Patton et al. (2007) and Cummins et al.
(2012) support these results found, finding that fertility genetic merit did not have an effect on circulating glucose and NEFA. The average levels of blood metabolites were within the threshold for healthy cows, therefore less likely to develop PP diseases known to negatively affect fertility (Compton et al., 2015). Regardless of the lack of significant difference in BCS or BCS loss between $\mathrm{G}$, there was, however, a significant difference in BW loss. The LFHM cows lost less BW over the first $60 \mathrm{~d}$ and lost less to reach BW nadir compared with the HFLM. As seen in Figure 3, LFHM had a lower BW at calving; therefore, HFLM cows had more BW to lose. For the period from 30 to $60 \mathrm{~d}$, LFHM cows lost 11.7 $\mathrm{kg}$ of BW compared with a small BW loss in the HFLM cows $(1.94 \mathrm{~kg}$ of $\mathrm{BW})$, indicating that majority of the BW loss occurred in the first $30 \mathrm{~d}$ for both genotypes. Additionally, LFHM cows gained BW more gradually whereas HFLM cows recovered quickly after reaching the BW nadir, resulting in a small BW loss between 30 and $60 \mathrm{~d} \mathrm{PP}$.

Uterine Recovery. First ovulation occurring within the first month PP is favorable for reproductive success (Galvão et al., 2010) and is largely dependent on the endocrinology of the cow, which is principally determined by energy balance PP (Lucy, 2019). The metabolites recorded in the present study suggest that cows were in an acceptable energy balance as the mean values are within the threshold of healthy cows as mentioned previously. Findings similar to those of O'Sullivan et al. (2019b) and other studies (Walsh et al., 2008; Bedere et al., 2016) were found in the present study, where progesterone variables used to identify PPAI were not affected by genotype. The poor fertility subindex in this study is just below the current national average (26.5 vs. 37.6, ICBF) and did not have a negative effect on the uterine recovery parameters recorded. Further research is needed to compare divergent subindexes within the EBI, not only in milk and fertility but also the inclusion of maintenance. Based on current outcomes, it is possible to have a high output herd with good milk-fat-plus-protein, maintenance, and fertility. However, caution is needed when interpreting these results because of the limited number of cows used.

\section{Effect of Nutritional Management and Genotype}

Few NM by G interactions were observed, with the majority of these occurring within the first $30 \mathrm{~d}$ PP in terms of milk production. The HFLM cows had a higher protein concentration $(3.72 \%)$ and casein concentration $(2.88 \mathrm{~g} / 100 \mathrm{~g}$ of milk) when grazing from d 1 compared with the HFLM cows on the TMR NM strategy ( $3.39 \%$ and $2.63 \mathrm{~g} / 100 \mathrm{~g}$ of milk, respectively). 
These results suggest that the HFLM cows responded better to a pasture-based diet than to a TMR-based diet compared with the LFHM cows.

The number of interactions was reduced to one interaction over a longer period of $100 \mathrm{~d}$ PP. The HFLM cows had increased lactose yield when fed under the TMR NM strategy whereas no significant difference was seen when LFHM cows were compared under the 2 NM strategies in this study. From the current study, it is apparent that HFLM cows respond differently to the contrasting NM strategies, as seen by results for milk composition in the first $30 \mathrm{~d} \mathrm{PP}$.

\section{CONCLUSIONS}

Offering TMR for the first $30 \mathrm{~d}$ followed by pasture allocation has benefits throughout early lactation. This NM strategy improves milk production and positively alters the energy status, metabolic profile, and BCS loss. These positive outcomes improve the health and welfare of the cow while simultaneously allowing farmers to build grass covers at times of poor growth and avoid pasture damage due to adverse weather conditions in early spring. This study indicated that low fertility and higher milk genetic merit did not negatively affect metabolic status, BCS maintenance, or uterine recovery, despite the tendency for a higher energy deficit. Further investigation is needed to build on these results because little knowledge is available on different nutrition strategies for contrasting cow genotypes to be used in high-output pasture-based systems.

\section{ACKNOWLEDGMENTS}

This experiment was funded by the Department of Agriculture, Food and Marine (DAFM; Dublin, Ireland) under the NutriGen project as part of the Research Stimulus Fund program 15/S/675. The authors thank the staff and students at University College Dublin who assisted during this experiment. The authors have not stated any conflicts of interest.

\section{REFERENCES}

Al Ibrahim, R. M., S. J. Whelan, K. M. Pierce, D. P. Campion, V. P. Gath, and F. J. Mulligan. 2013. Effect of timing of post-partum introduction to pasture and supplementation with Saccharomyces cerevisiae on milk production, metabolic status, energy balance and some reproductive parameters in early lactation dairy cows. J. Anim. Physiol. Anim. Nutr. (Berl.) 97:105-114. https://doi.org/ 10.1111/jpn.12048.

Astessiano, A. L., A. Meikle, M. Fajardo, J. Gil, D. A. Mattiauda, P. Chilibroste, and M. Carriquiry. 2015. Metabolic and endocrine profiles and hepatic gene expression of Holstein cows fed total mixed ration or pasture with different grazing strategies during early lactation. Acta Vet. Scand. 57:70. https://doi.org/10.1186/ s13028-015-0163-6.
Bargo, F., J. E. Delahoy, G. F. Schroeder, L. H. Baumgard, and L. D. Muller. 2006. Supplementing total mixed rations with pasture increase the content of conjugated linoleic acid in milk. Anim. Feed Sci. Technol. 131:226-240. https://doi.org/10.1016/j.anifeedsci .2006.04.017.

Bargo, F., L. D. Muller, E. S. Kolver, and J. E. Delahoy. 2003. Invited review: Production and digestion of supplemented dairy cows on pasture. J. Dairy Sci. 86:1-42. https://doi.org/10.3168/jds.S0022 -0302(03)73581-4.

Bedere, N., L. Delaby, V. Ducrocq, S. Leurent-Colette, and C. Disenhaus. 2016. Toward improved postpartum cyclicity of primiparous dairy cows: Effects of genetic merit for production traits under contrasting feeding systems. J. Dairy Sci. 99:1266-1276. https:// doi.org/10.3168/jds.2015-9843.

Berry, D. P., M. P. Coffey, J. E. Pryce, Y. De Haas, P. Løvendahl, N. Krattenmacher, J. J. Crowley, Z. Wang, D. Spurlock, K. Weigel, K. Macdonald, and R. F. Veerkamp. 2014. International genetic evaluations for feed intake in dairy cattle through the collation of data from multiple sources. J. Dairy Sci. 97:3894-3905. https://doi .org $/ 10.3168 /$ jds.2013-7548.

Berry, D. P., L. Shalloo, A. R. Cromie, V. Olori, R. F. Veerkamp, P. Dillon, P. R. Amer, R. D. Evans, J. F. Kearney, and B. Wickham. 2007. The economic breeding index: A generation on. A technical report to the Irish Cattle Breeding Federation. Accessed May, 20, 2020. https://www.researchgate.net/profile/Victor _Olori/publication/255594225_The_economic_breeding_index_a _generation_on/links/0a85e53c7890ee1187000000/The-economic -breeding-index-a-generation-on.pdf.

Berry, D. P., R. F. Veerkamp, and P. Dillon. 2006. Phenotypic profiles for body weight, body condition score, energy intake, and energy balance across different parities and concentrate feeding levels. Livest. Sci. 104:1-12. https://doi.org/10.1016/j.livsci.2006.02.012.

Burke, C. R., and J. R. Roche. 2007. Effects of pasture feeding during the periparturient period on postpartum anovulation in grazed dairy cows. J. Dairy Sci. 90:4304-4312. https://doi.org/10.3168/ jds.2006-788.

Burke, C. R., Y. J. Williams, L. Hofmann, J. K. Kay, C. V. C. Phyn, and S. Meier. 2010. Effects of an acute feed restriction at the onset of the seasonal breeding period on reproductive performance and milk production in pasture-grazed dairy cows. J. Dairy Sci. 93:1116-1125. https://doi.org/10.3168/jds.2009-2562.

Butler, W. R. 2003. Energy balance relationships with follicular development, ovulation and fertility in postpartum dairy cows. Livest. Prod. Sci. 83:211-218. https://doi.org/10.1016/S0301 -6226(03)00112-X.

Chilliard, Y., M. Cissé, R. Lefaivre, and B. Rémond. 1991. Body composition of dairy cows according to lactation stage, somatotropin treatment, and concentrate supplementation. J. Dairy Sci. 74:3103-3116. https://doi.org/10.3168/jds.S0022-0302(91)78496 $-8$.

Claffey, A., L. Delaby, E. Lewis, T. M. Boland, and E. Kennedy. 2019 Pasture allowance, duration, and stage of lactation-Effects on early and total lactation animal performance. J. Dairy Sci. 102:89868998. https://doi.org/10.3168/jds.2018-15784.

Compton, C. W. R., L. Young, and S. McDougall. 2015. Subclinical ketosis in post-partum dairy cows fed a predominantly pasturebased diet: Defining cut-points for diagnosis using concentrations of beta-hydroxybutyrate in blood and determining prevalence. N. Z. Vet. J. 63:241-248. https://doi.org/10.1080/00480169.2014 .999841.

Couvreur, S., C. Hurtaud, C. Lopez, L. Delaby, and J. L. Peyraud. 2006. The linear relationship between the proportion of fresh grass in the cow diet, milk fatty acid composition, and butter properties. J. Dairy Sci. 89:1956-1969. https://doi.org/10.3168/jds.S0022 -0302(06)72263-9.

Cummins, S. B., P. Lonergan, A. C. O. Evans, D. P. Berry, R. D. Evans, and S. T. Butler. 2012. Genetic merit for fertility traits in Holstein cows: I. Production characteristics and reproductive efficiency in a pasture-based system. J. Dairy Sci. 95:1310-1322. https://doi.org/10.3168/jds.2011-4742. 
Curran, F. 2016. Nutritional effects on fertility in pasture-based systems. PhD Thesis. Animal and Bioscience Research Department, Animal and Grassland Research and Innovation Centre, Teagasc Moorepark, Co. Cork, Ireland.

Dillon, P., J. R. Roche, L. Shalloo, and B. Horan. 2005, July. Optimising financial return from grazing in temperate pastures. Pages 131-147 in Proc. Satellite Workshop of the XXth International Grassland Congress, Cork, Ireland. J. J. Murphy, ed. Wageningen Academic Publishers, Wageningen, the Netherlands.

Dove, H., and R. W. Mayes. 2006. Protocol for the analysis of n-alkanes and other plant-wax compounds and for their use as markers for quantifying the nutrient supply of large mammalian herbivores. Nat. Protoc. 1:1680-16978.

Drackley, J. K., and J. B. Andersen. 2006. Splanchnic metabolism of long-chain fatty acids in ruminants. Pages 199-224 in Ruminant Physiology: Digestion, Metabolism and Impact of Nutrition on Gene Expression, Immunology and Stress. K. Sejrsen, T. Hvelplund and M. O. Nielsen, ed. Wageningen Academic Publishers, Netherlands.

DuBois, M., K. A. Gilles, J. K. Hamilton, P. T. Rebers, and F. Smith. 1956. Colorimetric method for determination of sugars and related substances. Anal. Chem. 28:350-356. https://doi.org/10.1021/ ac60111a017.

Edmonson, A. J., I. J. Lean, L. D. Weaver, T. Farver, and G. Webster. 1989. A body condition scoring chart for Holstein dairy cows. J. Dairy Sci. 72:68-78. https://doi.org/10.3168/jds.S0022 -0302(89)79081-0.

Fahey, A. G., R. M. Marchant-Forde, and H. W. Cheng. 2007. Relationship between body weight and beak characteristics in one-dayold white leghorn chicks: its implications for beak trimming. Poult. Sci. 86:1312-1315. https://doi.org/10.1093/ps/86.7.1312.

Ferris, C. P. 2007. Sustainable pasture based dairy systems-meeting the challenges. Can. J. Plant Sci. 87:723-738. https://doi.org/10 4141/CJPS06011.

Finneran, E., P. Crosson, P. O'Kiely, L. Shalloo, D. Forristal, and M. Wallace. 2010. Simulation modelling of the cost of producing and utilising feeds for ruminants on Irish farms. J. Farm Manag. 14:95-116.

Fulkerson, W. J., T. M. Davison, S. C. Garcia, G. Hough, M. E. Goddard, R. Dobos, and M. Blockey. 2008. Holstein-Friesian dairy cows under a predominantly grazing system: Interaction between genotype and environment. J. Dairy Sci. 91:826-839. https://doi .org/10.3168/jds.2007-0147.

Gaines, W. L., and F. A. Davidson. 1923. Relation between percentage fat content and yield of milk: correction of milk yield for fat content. Univ. Illinois Agric. Exp. Station Bull. 245, Univ. of Illinois, Urbana.

Galvão, K. N., M. J. B. F. Flaminio, S. B. Brittin, R. Sper, M. Fraga, L. Caixeta, A. Ricci, C. L. Guard, W. R. Butler, and R. O. Gilbert. 2010. Association between uterine disease and indicators of neutrophil and systemic energy status in lactating Holstein cows. J. Dairy Sci. 93:2926-2937. https://doi.org/10.3168/jds.2009-2551.

Garnsworthy, P. C., K. D. Sinclair, and R. Webb. 2008. Integration of physiological mechanisms that influence fertility in dairy cows. Animal 2:1144-1152. https://doi.org/10.1017/S1751731108002358.

Gautam, G., T. Nakao, K. Yamada, and C. Yoshida. 2010. Defining delayed resumption of ovarian activity postpartum and its impact on subsequent reproductive performance in Holstein cows. Theriogenology 73:180-189.

Gong, J. G., W. J. Lee, P. C. Garnsworthy, and R. Webb. 2002. Effect of dietary-induced increases in circulating insulin concentrations during the early postpartum period on reproductive function in dairy cows. Reproduction 123:419-427. https://doi.org/10.1530/ rep.0.1230419.

Gulati, A., N. Galvin, E. Lewis, D. Hennessy, M. O'Donovan, J. J. McManus, M. A. Fenelon, and T. P. Guinee. 2018. Outdoor grazing of dairy cows on pasture versus indoor feeding on total mixed ration: Effects on gross composition and mineral content of milk during lactation. J. Dairy Sci. 101:2710-2723. https://doi.org/10 $.3168 /$ jds.2017-13338.
Hammon, D. S., I. M. Evjen, T. R. Dhiman, J. P. Goff, and J. L. Walters. 2006. Neutrophil function and energy status in Holstein cows with uterine health disorders. Vet. Immunol. Immunopathol. 113:21-29. https://doi.org/10.1016/j.vetimm.2006.03.022.

Heppelmann, M., A. Brömmling, M. Weinert, M. Piechotta, C. Wrenzycki, and H. Bollwein. 2013. Effect of postpartum suppression of ovulation on uterine involution in dairy cows. Theriogenology 80:519-525. https://doi.org/10.1016/j.theriogenology.2013.05.017.

Horan, B., P. Dillon, P. Faverdin, L. Delaby, F. Buckley, and M. Rath. 2005. The interaction of strain of Holstein-Friesian cows and pasture-based feed systems on milk yield, body weight, and body condition score. J. Dairy Sci. 88:1231-1243. https://doi.org/10.3168/ jds.S0022-0302(05)72790-9.

Horan, B., P. Faverdin, L. Delaby, M. Rath, and P. Dillon. 2006. The effect of strain of Holstein-Friesian dairy cow and pasture-based system on grass intake and milk production. Anim. Sci. 82:435444. https://doi.org/10.1079/ASC200661.

Ingvartsen, K. L., R. J. Dewhurst, and N. C. Friggens. 2003. On the relationship between lactational performance and health: Is it yield or metabolic imbalance that cause production diseases in dairy cattle? A position paper. Livest. Prod. Sci. 83:277-308. https:// doi.org/10.1016/S0301-6226(03)00110-6.

Jarrige, R. 1989. Ruminant Nutrition: Recommended Allowances and Feed Tables. Institut National de la Recherche Agronomique, Paris, France.

Kennedy, E., L. Delaby, B. Horan, J. Roche, and E. Lewis. 2015, June. Duration is important in the effect of pasture allowance restriction on subsequent milk. Pages 110-112 in Grassland and Forages in High Output Dairy Farming Systems. Symposium of the European Grassland Federation, Wageningen, the Netherlands. Wageningen Academic Publishers, the Netherlands.

Kennedy, J., P. Dillon, L. Delaby, P. Faverdin, G. Stakelum, and M. Rath. 2003. Effect of genetic merit and concentrate supplementation on grass intake and milk production with Holstein Friesian dairy cows. J. Dairy Sci. 86:610-621. https://doi.org/10.3168/jds .S0022-0302(03)73639-X.

Kolver, E. S. 2003. Nutritional limitations to increased production on pasture-based systems. Proc. Nutr. Soc. 62:291-300. https://doi .org/10.1079/PNS2002200.

Kolver, E. S., and L. D. Muller. 1998. Performance and nutrient intake of high producing Holstein cows consuming pasture or a total mixed ration. J. Dairy Sci. 81:1403-1411. https://doi.org/10.3168/ jds.S0022-0302(98)75704-2.

Kolver, E. S., J. R. Roche, M. De Veth, P. Thorne, and A. R. Napper. 2002. Total mixed ration versus pasture diets: Evidence of a genotype $\times$ diet interaction. Proc. N.Z. Soc. Anim. Prod. 62:246-251.

Loor, J. J., F. D. Soriano, X. Lin, J. H. Herbein, and C. E. Polan. 2003. Grazing allowance after the morning or afternoon milking for lactating cows fed a total mixed ration (TMR) enhances trans11-18: 1 and cis9, trans11-18: 2 (rumenic acid) in milk fat to different extents. Anim. Feed Sci. Technol. 109:105-119. https:// doi.org/10.1016/S0377-8401(03)00175-5.

Lucy, M. C. 2019. Symposium review: Selection for fertility in the modern dairy cow - Current status and future direction for genetic selection. J. Dairy Sci. 102:3706-3721. https://doi.org/10.3168/jds 2018-15544.

Lucy, M.C., G.A. Verkerk, B.E. Whyte, K.A. Macdonald, L. Burton, R.T. Cursons, J.R. Roche, and C.W. Holmes., 2009. Somatotropic axis components and nutrient partitioning in genetically diverse dairy cows managed under different feed allowances in a pasture system. J. Dairy Sci. 92:526-539. https://doi.org/10.3168/jds.2008 $-1421$.

Mayes, R. W., C. S. Lamb, and P. M. Colgrove. 1986. The use of dosed and herbage n-alkanes as markers for the determination of herbage intake. J. Agric. Sci. 107:161-170. https://doi.org/10.1017/ S0021859600066910.

McCarthy, S., D. P. Berry, P. Dillon, M. Rath, and B. Horan. 2007. Influence of Holstein-Friesian strain and feed system on body weight and body condition score lactation profiles. J. Dairy Sci. 90:18591869. https://doi.org/10.3168/jds.2006-501. 
McDougall, S., S. Leane, S. T. Butler, J. R. Roche, and C. R. Burke. 2018. Effect of altering the type of dietary carbohydrate early postpartum on reproductive performance and milk production in pasture-grazed dairy cows. J. Dairy Sci. 101:3433-3446. https:// doi.org/10.3168/jds.2016-12421.

McParland, S., E. Kennedy, E. Lewis, S. G. Moore, B. McCarthy, M. O'Donovan, and D. P. Berry. 2015. Genetic parameters of dairy cow energy intake and body energy status predicted using midinfrared spectrometry of milk. J. Dairy Sci. 98:1310-1320. https:/ /doi.org/10.3168/jds.2014-8892.

Miglior, F., A. Fleming, F. Malchiodi, L. F. Brito, P. Martin, and C. F. Baes. 2017. A 100-Year Review: Identification and genetic selection of economically important traits in dairy cattle. J. Dairy Sci. 100:10251-10271. https://doi.org/10.3168/jds.2017-12968.

Moore, S. G., T. Fair, P. Lonergan, and S. T. Butler. 2014. Genetic merit for fertility traits in Holstein cows: IV. Transition period, uterine health, and resumption of cyclicity. J. Dairy Sci. 97:27402752. https://doi.org/10.3168/jds.2013-7278.

O'Callaghan, T. F., D. Hennessy, S. McAuliffe, K. N. Kilcawley, M. O'Donovan, P. Dillon, R. P. Ross, and C. Stanton. 2016. Effect of pasture versus indoor feeding systems on raw milk composition and quality over an entire lactation. J. Dairy Sci. 99:9424-9440. https://doi.org/10.3168/jds.2016-10985.

O'Donovan, M., J. Connolly, P. Dillon, M. Rath, and G. Stakelum. 2002. Visual assessment of herbage mass. Ir. J. Agric. Food Res. 41:201-211. https://www.jstor.org/stable/25562464.

O'Neill, B. F., M. H. Deighton, B. M. O'Loughlin, F. J. Mulligan, T. M. Boland, M. O'Donovan, and E. Lewis. 2011. Effects of a perennial ryegrass diet or total mixed ration diet offered to springcalving Holstein Friesian dairy cows on methane emissions, dry matter intake, and milk production. J. Dairy Sci. 94:1941-1951. https://doi.org/10.3168/jds.2010-3361.

O'Sullivan, M., S. T. Butler, K. M. Pierce, M. A. Crowe, K. O'Sullivan, R. Fitzgerald, and F. Buckley. 2020. Reproductive efficiency and survival of Holstein-Friesian cows of divergent Economic Breeding Index, evaluated under seasonal calving pasture-based management. J. Dairy Sci. 103:1685-1700. https://doi.org/10.3168/jds 2019-17374.

O'Sullivan, M., P. Dillon, K. O'Sullivan, K. M. Pierce, N. Galvin, M. Egan, and F. Buckley. 2019a. Intake, efficiency, and feeding behavior characteristics of Holstein-Friesian cows of divergent Economic Breeding Index evaluated under contrasting pasture-based feeding treatments. J. Dairy Sci. 102:8234-8246. https://doi.org/10.3168/ jds.2019-16371.

O'Sullivan, M., B. Horan, K. M. Pierce, S. McParland, K. O'Sullivan, and F. Buckley. 2019b. Milk production of Holstein-Friesian cows of divergent Economic Breeding Index evaluated under seasonal pasture-based management. J. Dairy Sci. 102:2560-2577. https:// doi.org/10.3168/jds.2018-15559.

Ospina, P. A., D. V. Nydam, T. Stokol, and T. R. Overton. 2010 Evaluation of nonesterified fatty acids and $\beta$-hydroxybutyrate in transition dairy cattle in the northeastern United States: Critical thresholds for prediction of clinical diseases. J. Dairy Sci. 93:546554. https://doi.org/10.3168/jds.2009-2277.

Patton, J., D. A. Kenny, S. McNamara, J. F. Mee, F. P. O'Mara, M. G. Diskin, and J. J. Murphy. 2007. Relationships among milk production, energy balance, plasma analytes, and reproduction in Holstein-Friesian cows. J. Dairy Sci. 90:649-658. https://doi.org/ 10.3168/jds.S0022-0302(07)71547-3.

Penner, G. B., K. A. Beauchemin, and T. Mutsvangwa. 2007. Severity of ruminal acidosis in primiparous Holstein cows during the periparturient period. J. Dairy Sci. 90:365-375. https://doi.org/10 $.3168 /$ jds.S0022-0302(07)72638-3.

Roche, J. R., J. K. Kay, C. V. C. Phyn, S. Meier, J. M. Lee, and C. R. Burke. 2010. Dietary structural to nonfiber carbohydrate concentration during the transition period in grazing dairy cows. J. Dairy Sci. 93:3671-3683. https://doi.org/10.3168/jds.2009-2868.

Šavc, M., M. Duane, L. E. O'Grady, J. R. Somers, and M. E. Beltman. 2016. Uterine disease and its effect on subsequent reproductive performance of dairy cattle: A comparison of two cow-side diag- nostic methods. Theriogenology 86:1983-1988. https://doi.org/10 $.1016 / j$.theriogenology.2016.06.018.

Sheldon, I. M., and S. E. Owens. 2017. Postpartum uterine infection and endometritis in dairy cattle. Anim. Reprod. 14:622-629. https: //doi.org/10.21451/1984-3143-AR1006.

Smit, H. J., A. Elgersma, A. Lúscher, B. Jeangros, W. Kessler, O. Huguenin, M. Lobsiger, N. Millar, and D. Suter. 2004. Diurnal fluctuations in vertical distribution of chemical composition in perennial ryegrass (Lolium perenne L.) sward during the season. Pages 951-953 in Proc. 20th General Meeting of the European Grassland Federation, Luzern, Switzerland. VDF Hochschlugverlag AG and der ETH, Zurich, Switzerland.

Soyeurt, H., P. Dardenne, F. Dehareng, G. Lognay, D. Veselko, M. Marlier, C. Bertozzi, P. Mayeres, and N. Gengler. 2006. Estimating fatty acid content in cow milk using mid-infrared spectrometry. J. Dairy Sci. 89:3690-3695. https://doi.org/10.3168/jds.S0022 -0302(06)72409-2.

van Knegsel, A. T. M., H. van den Brand, J. Dijkstra, W. M. Van Straalen, M. J. W. Heetkamp, S. Tamminga, and B. Kemp. 2007b. Dietary energy source in dairy cows in early lactation: energy partitioning and milk composition. J. Dairy Sci. 90:1467-1476. https: //doi.org/10.3168/jds.S0022-0302(07)71632-6.

van Knegsel, A. T. M., H. van den Brand, J. Dijkstra, W. M. Van Straalen, R. Jorritsma, S. Tamminga, and B. Kemp. 2007a. Effect of glucogenic vs. lipogenic diets on energy balance, blood metabolites, and reproduction in primiparous and multiparous dairy cows in early lactation. J. Dairy Sci. 90:3397-3409. https://doi.org/10 $.3168 /$ jds.2006-837.

Van Soest, P. J., J. B. Robertson, and B. A. Lewis. 1991. Methods for dietary fiber, neutral detergent fiber, and nonstarch polysaccharides in relation to animal nutrition. J. Dairy Sci. 74:3583-3597. https://doi.org/10.3168/jds.S0022-0302(91)78551-2.

Veerkamp, R. F., and S. Brotherstone. 1997. Genetic correlations between linear type traits, food intake, live weight and condition score in Holstein Friesian dairy cattle. Anim. Sci. 64:385-392. https://doi.org/10.1017/S1357729800015976.

Veerkamp, R. F., P. Dillon, E. Kelly, A. R. Cromie, and A. F. Groen. 2002. Dairy cattle breeding objectives combining yield, survival and calving interval for pasture-based systems in Ireland under different milk quota scenarios. Livest. Prod. Sci. 76:137-151. https: //doi.org/10.1016/S0301-6226(02)00006-4.

Walsh, S., F. Buckley, K. Pierce, N. Byrne, J. Patton, and P. Dillon. 2008. Effects of breed and feeding system on milk production, body weight, body condition score, reproductive performance, and postpartum ovarian function. J. Dairy Sci. 91:4401-4413. https:// doi.org/10.3168/jds.2007-0818.

Westwood, C. T., I. J. Lean, J. K. Garvin, and P. C. Wynn. 2000. Effects of genetic merit and varying dietary protein degradability on lactating dairy cows. J. Dairy Sci. 83:2926-2940. https://doi.org/ 10.3168/jds.S0022-0302(00)75193-9.

Whelan, S. J., K. M. Pierce, C. McCarney, B. Flynn, and F. J. Mulligan. 2012. Effect of supplementary concentrate type on nitrogen partitioning in early lactation dairy cows offered perennial ryegrass-based pasture. J. Dairy Sci. 995:4468-4477. https://doi .org/10.3168/jds.2011-4689.

Williams, E. J., D. P. Fischer, D. U. Pfeiffer, G. C. England, D. E. Noakes, H. Dobson, and I. M. Sheldon. 2005. Clinical evaluation of postpartum vaginal mucus reflects uterine bacterial infection and the immune response in cattle. Theriogenology 63:102-117. https: //doi.org/10.1016/j.theriogenology.2004.03.017.

\section{ORCIDS}

E. L. Brady (으 https://orcid.org/0000-0003-4447-0015

K. M. Pierce @ https://orcid.org/0000-0002-2056-6189

M. B. Lynch (1) https://orcid.org/0000-0002-5301-6845

A. G. Fahey (1) https://orcid.org/0000-0002-4594-5767

F. J. Mulligan ( ) https://orcid.org/0000-0002-1787-0788 